\title{
9. AN INTEGRATED BIOCHEMICAL, GEOCHEMICAL, AND SEDIMENTOLOGICAL STUDY OF ORGANIC DIAGENESIS IN SEDIMENTS FROM LEG 1121
}

\author{
R. L. Patience, ${ }^{2}$ C. J. Clayton, ${ }^{2}$ A. T. Kearsley,${ }^{3}$ S. J. Rowland, ${ }^{4}$ A. N. Bishop, ${ }^{3,5}$ A.W.G. Rees, ${ }^{4}$ K. G. Bibby, ${ }^{2}$ \\ and A. C. Hopper ${ }^{2}$
}

\begin{abstract}
Organic-rich diatomaceous muds from Ocean Drilling Program Leg 112 (offshore Peru) are the subject of a comprehensive organic diagenetic study covering the burial interval, $<1$ to $>100 \mathrm{~m}$. The organic matter has been classified in terms of its elemental, biochemical, and geochemical compositions. About $60 \%$ of the organic carbon in sediments from $<1 \mathrm{~m}$ can be attributed to hydrolyzable, biochemical constituents, while at $22 \mathrm{~m}$ this figure decreased to $20 \%$. Pyrolysis-gas chromatography and gas chromatography-mass spectrometry chromatograms of these same sediments contain mainly hydrocarbons and nitrogenous compounds, with low amounts of other heteroatomic compounds, even though the total organic matter is rich in oxygen (about 35 atoms per 100 carbon atoms) and sulfur ( 1 to 5 atoms per $100 \mathrm{C}$ atoms). Overall, the organic matter in these sediments, even at these shallow depths and young ages, has many of the geochemical features of far more deeply buried sediments, providing further strong evidence for the claim that "kerogen-formation" is a very early diagenetic process.
\end{abstract}

\section{INTRODUCTION}

The diagenesis of organic matter in modern sediments has been the topic of a great number of studies over the years. This subject has been approached from many different angles, such as (1) the fate of biochemical influxes, notably amino acids and carbohydrates; (2) changes in the distributions of specific lipid classes such as sterols and hydrocarbons; (3) changes in elemental composition; (4) the origin of the so-called humic compounds; and (5) the formation of (proto-)kerogen. Readers are referred to Romankevich (1984) for a general review of many such studies and to Tissot and Welte (1984) for a general discussion of organic diagenesis. This body of published work has contributed substantially to our understanding of diagenetic processes, yet there is one approach that has rarely been discussed. Perhaps mainly for logistical reasons, nearly all diagenetic studies have concentrated on only a fraction of the organic matter (e.g., amino acids). A few previous studies tried to characterize all of the organic matter in a surface sediment (e.g., Klok et al., 1983, 1984; Bhosle and Dhople, 1988), while others have reported the diagenesis of either individual biochemical classes (e.g., amino acids, Brown et al., 1972; sugars, Vallentyne, 1963) or the total hydrolyzable fraction (Bordovskiy, 1965; Huc et al., 1978). None, to our knowledge, has investigated diagenetic changes in composition, for all the major biochemical classes separately, over a range of burial depths and at the same site.

We have tried to fill this gap by applying a number of analytical techniques, both biochemical and geochemical, to organic-rich sediments from the Peru upwelling region, which

\footnotetext{
${ }^{1}$ Suess, E., von Huene, R., et al., 1990. Proc. ODP, Sci. Results, 112: College Station, TX (Ocean Drilling Program).

2 Exploration Technology Branch, BP Research Centre, Chertsey Rd., Sunbury-on-Thames, Middlesex TW16 7LN, United Kingdom.

${ }^{3}$ Dept. of Geology, Oxford Polytechnic, Gipsy Lane, Oxford OX3 OBP, United Kingdom.

${ }^{4}$ Dept. of Environmental Sciences, Polytechnic Southwest, Drake Circus, Plymouth, Devon PL4 8AA, United Kingdom.

${ }^{5}$ Present Address: Organic Geochemistry Unit, Drummond Bldg., Univ. of Newcastle, Newcastle-upon-Tyne, United Kingdom.
}

was cored during Leg 112. In this way, we hope to gain a clearer picture of the processes that occur during kerogen formation. Biochemical methods were applied to categorize these sediments in terms of the three major fractions used to classify living organisms (lipids, proteins, and carbohydrates). A combination of elemental analysis, pyrolysis (py), py-gas chromatography (pyGC), and pyGC-mass spectrometry (pyGCMS) was used to derive standard geochemical information about the organic matter, while solid-state ${ }^{13} \mathrm{C}$ nuclear magnetic resonance $\left({ }^{13} \mathrm{C}\right.$-NMR) spectroscopy provided general structural information about aromaticity and organic oxygen functionality. Finally, elemental analysis and sophisticated scanning electron microscopy (SEM) were used in tandem to locate and quantify the organic matter in individual, lamina-scale samples.

\section{EXPERIMENTAL METHODS}

\section{Preparation of Samples}

With the exception of those used for SEM analysis, all samples arrived frozen and were freeze-dried before storage as dry powders in a nitrogen atmosphere. The samples used for elemental, biochemical, geochemical, and NMR analyses are described in Table 1. The SEM samples, and the technique itself, are described in the "Scanning Electron Microscopy" section (this chapter).

\section{Elemental Analysis}

Acid-soluble material was removed by treating with concentrated $\mathrm{HCl}$ at room temperature. The residue was washed with water and dried, and the elemental composition determined as follows:

$\mathrm{CHN}$ analyses for carbon, hydrogen, and nitrogen were conducted using a Carlo Erba 1106 elemental analyzer. Pyrolyzable oxygen was also determined using the same instrument, but under pyrolysis conditions. Complete experimental conditions are given in the Appendix.

All other elements were determined by X-ray fluorescence (XRF) smear analysis, using a Phillips wavelength dispersive XRF spectrophotometer, model PW1400.

Elemental compositions then were adjusted to account for the weight loss as a result of acid treatment. 
Table 1. Depth and lithological descriptions for the bulk samples.

\begin{tabular}{|c|c|c|c|c|}
\hline $\begin{array}{l}\text { Core, section, } \\
\text { interval }(\mathrm{cm})\end{array}$ & $\begin{array}{l}\text { Depth } \\
\text { (mbsf) }\end{array}$ & $\begin{array}{l}\text { Lith. } \\
\text { unit }\end{array}$ & Epoch & Lithology \\
\hline $112-679 D-1-1,25-35$ & $0.25-0.35$ & I & Holocene-Pleistocene & Diatomaceous/foraminiferal mud. \\
\hline $1-1,73-83$ & $0.73-0.83$ & I & & \\
\hline $1-2,131-141$ & $2.81-2.91$ & I & & \\
\hline $1-4,88-98$ & $5.38-5.48$ & I & & \\
\hline $2-2,48-58$ & $9.88-9.98$ & I & & \\
\hline $5-2,111-123$ & $39.01-39.13$ & I & & \\
\hline $9-1,59-71$ & $74.99-75.11$ & II & Pleistocene-Pliocene & Diatomaceous mud. \\
\hline $17 X-1,108-116$ & $143.48-143.56$ & III & early Pliocene-late Miocene & Interbedded diatomaceous mud/silt/sand. \\
\hline $12 X-1,88-96$ & $347.68-347.76$ & $\mathrm{~V}$ & middle Miocene & Laminated black shale. \\
\hline $112-680 \mathrm{~B}-1-1,29-41^{\mathrm{a}}$ & $0.29-0.41$ & I & Holocene-latest Pleistocene & Diatomaceous/foaminiferal mud. \\
\hline $1-1,70-82^{\mathrm{a}}$ & $0.70-0.82$ & I & & \\
\hline $1-4,26-34$ & $4.76-4.84$ & I & & \\
\hline $2-3,29-37$ & $8.79-8.87$ & I & & \\
\hline $3-5,129-139$ & $22.29-22.39$ & I & & \\
\hline $10-6,88-100$ & $89.88-90.00$ & IIIC & Pleistocene-lower Pliocene & Diatomaceous mud. \\
\hline $112-681 \mathrm{~B}-1-1,36-44$ & $0.36-0.44$ & I & Holocene-Pleistocene & Diatomaceous mud. \\
\hline $1-1,81-89$ & $0.81-0.89$ & I & & \\
\hline $2-2,83-91$ & $8.23-8.31$ & I & & \\
\hline $2-5,34-42$ & $12.24-12.32$ & I & & \\
\hline $5-5,57-69$ & $40.97-41.09$ & II & Pleistocene & Interbedded diatomaceous mud and \\
\hline $10-2,120-131$ & $84.60-84.71$ & II & & terrigenous sequences. \\
\hline $13 X-5,100-112$ & $112.50-112.62$ & III & Pleistocene & Diatomaceous mud. \\
\hline $112-686 \mathrm{~B}-1-1,30-39$ & $0.30-0.39$ & I & Holocene-Pleistocene & Sandy diatomaceous mud-some \\
\hline $1-1,87-96$ & $0.87-0.96$ & I & & burrowing. \\
\hline $1-3,79-89$ & $3.79-3.89$ & I & & \\
\hline $1-5,80-90$ & $6.80-6.90$ & I & & \\
\hline $3-2,33-45$ & $19.83-19.95$ & $\mathrm{I}$ & & \\
\hline $9 X-5,30-44$ & $80.08-80.22$ & II & Pleistocene & $\begin{array}{l}\text { Burrowed sandy diatomaceous muds, } \\
\text { silts sands. }\end{array}$ \\
\hline $112-686 \mathrm{~B}-15 \mathrm{X}-5,32-42$ & $138.32-138.42$ & III & Pleistocene & Laminated diatomaceous muds. \\
\hline
\end{tabular}

${ }^{a}$ Drilling disturbance and soupy mud in first meter.

\section{Biochemical Analysis}

\section{Extraction Scheme}

All extractions and hydrolyses were performed in centrifuge tubes having ground glass joints to minimize the need for transferring the solutions and sediments.

\section{Aqueous Extraction}

The freeze-dried sediment (about $1 \mathrm{~g}$ ) was weighed into a centrifuge tube and extracted with water $(2$ times $10 \mathrm{~mL})$. For each extraction, the sample was agitated at room temperature using a Miximatic (Jencons) (4 min) and then centrifuged (3000 $\mathrm{rpm} ; 5 \mathrm{~min}$ ). The supernatants were transferred to a measuring cylinder $(25 \mathrm{~mL})$, mixed and divided into three aliquots: the first was adjusted to $\mathrm{pH} 9$ to 10 with $0.1 \mathrm{~mol} / \mathrm{L} \mathrm{KOH}$ and kept for volatile fatty acid (VFA) analysis (these results are not available here). The second was freeze-dried and then hydrolyzed with $6 \mathrm{~mol} / \mathrm{L} \mathrm{HCl}(10 \mathrm{~mL})$ for $22 \mathrm{hr}$. The hydrolyzate was freeze-dried, redissolved in a known volume of $0.1 \mathrm{~mol} / \mathrm{L}$ $\mathrm{KOH}$ and analyzed for amino acid content (see Appendix). The third aliquot was also freeze-dried and then hydrolyzed with $1 \mathrm{~mol} / \mathrm{L} \mathrm{H}_{2} \mathrm{SO}_{4}(10 \mathrm{~mL})$ for $22 \mathrm{hr}$. The hydrolysate was freeze-dried, redissolved in a known volume of $0.1 \mathrm{~mol} / \mathrm{L}$ $\mathrm{KOH}$ and analyzed for monosaccharide content (see Appendix).

The residue after the aqueous extraction was then dried in vacuo at $40^{\circ} \mathrm{C}$.

\section{Solvent Extraction}

Free lipids were obtained by solvent extraction. The solvent system used was methanol (2 times $10 \mathrm{~mL})$; dichloromethane/methanol $(\mathrm{DCM} / \mathrm{MeOH} ; 1: 1)(10 \mathrm{~mL})$; DCM (2 times $10 \mathrm{~mL}) ; \mathrm{DCM} / \mathrm{MeOH}(1: 1)$ (4 times $10 \mathrm{~mL})$, with mixing and centrifugation periods as for aqueous extraction.
After extraction, the supernatants were combined and transferred to a round-bottomed flask, and the solvent was removed by rotary evaporation. This extract was transferred to a 1-dram vial and dried under nitrogen. Lipids were quantified initially by weight, and these results then checked by the Iatroscan method (see Appendix).

The residue from the solvent extraction was dried in vacuo at $40^{\circ} \mathrm{C}$, then weighed and divided into three portions, which were treated as described next.

\section{The "Bound" Fraction}

One portion of the dried residual sediment was hydrolyzed ( 6 times) under reflux with $6 \mathrm{~mol} / \mathrm{L} \mathrm{HCl}(10 \mathrm{~mL})$ for $4 \mathrm{hr}$ per hydrolysis. After each hydrolysis, the tube was centrifuged and the supernatants combined and transferred to a roundbottomed flask. After the sixth hydrolysis, the sediment was washed with water ( 2 times $10 \mathrm{~mL}$ ) and the washings combined with the hydrolysate. This solution was then divided into two equal aliquots. One was adjusted to $\mathrm{pH} 9$ to 10 and kept for VFA analysis. The second portion was freeze-dried and then redissolved in a known volume of $0.1 \mathrm{~mol} / \mathrm{L} \mathrm{KOH}$, ready for amino acid analysis.

The second portion of the dried residual sediment was hydrolyzed under reflux with $1 \mathrm{~mol} / \mathrm{L} \mathrm{H}_{2} \mathrm{SO}_{4}$ in an identical manner to that described above, and used for the carbohydrate determination (see Appendix).

The third portion of the dried residual sediment was saponified by refluxing with $0.5 \mathrm{~mol} / \mathrm{L} \mathrm{KOH}$ in $\mathrm{MeOH}(10 \mathrm{~mL})$ for $4 \mathrm{hr}$. After acidification with $6 \mathrm{~mol} / \mathrm{L} \mathrm{HCl}$ to $\mathrm{pH}<5$, the solution was centrifuged and the aqueous layer transferred to a second tube. The residual sediment was extracted with DCM (2 times $10 \mathrm{~mL})$ and the aqueous layer with DCM (3 times $10 \mathrm{~mL}$ ). The organic solvent extracts were combined in a round-bottomed flask and rotary evaporated to dryness. The 
extract was transferred to a 1-dram vial and dried under nitrogen for lipid determination.

\section{Conversion to Sediment Concentrations}

Concentrations of lipids, carbohydrates, and proteins were obtained in a variety of units. Lipids were quantified as milligrams of total lipid, carbohydrates as milligrams of glucose equivalents, and proteins as millimoles of glycine equivalents. These were converted to the percentage of organic carbon in each biochemical fraction as a function of the total organic carbon present in the sediment, using the following calculations:

1. Lipids: the weight of each lipid fraction was converted to a weight of organic carbon by assuming that lipids contain $75 \%$ (by weight) carbon (e.g., palmitic acid). This weight was then converted to a percentage, knowing the weight of sediment sample from which it came and by dividing the lipid carbon weight by the calculated sediment organic-carbon weight.

2. Carbohydrates: we assumed that glucose is a representative monosaccharide, thus the weight obtained was converted to a weight of organic carbon from the knowledge that glucose contains $40 \%$ (by weight) carbon. This weight was converted to a percentage as for the lipids.

3. Proteins: these were quantified as millimoles of glycine equivalents. However, the molecular weight of glycine is not typical of the protein amino acids, in that it is too low. A value of 122.5 was used to represent an average amino acid; this was calculated from data in Klok et al. (1983), who identified individual amino acids in sediments from the Namibian shelf region off west Africa. The weight of proteins thus obtained was converted to weight of organic carbon by assuming that an average amino acid contains $45 \%$ (by weight) carbon. The remainder of the calculation was performed as above.

\section{Geochemical Analysis}

Pyrolysis yields $\left(\mathrm{S}_{1}\right.$ and $\left.\mathrm{S}_{2}\right)$ of whole sediments were obtained by heating at $250^{\circ} \mathrm{C}$ for $3 \mathrm{~min}\left(\mathrm{~S}_{1}\right)$, followed by heating at $30^{\circ} \mathrm{C} / \mathrm{min}$ from $250^{\circ}$ to $550^{\circ} \mathrm{C}\left(\mathrm{S}_{2}\right)$. Pyrolyzed and volatilized products were detected by flame ionization detector (FID).

For pyGC, the above pyrolysis conditions were also used; the $S_{2}$ products were chromatographed on an aluminum-clad BP-1 fused silica column $(25 \mathrm{~m} \times 0.53 \mathrm{~mm}$ internal diameter, SGE Co.). The column temperature was programmed from $-80^{\circ}$ to $0^{\circ} \mathrm{C}$ at $16^{\circ} \mathrm{C} / \mathrm{min}$, followed by $0^{\circ}$ to $300^{\circ} \mathrm{C}$ at $8^{\circ} \mathrm{C} / \mathrm{min}$. Helium was used as the carrier gas and detection was by FID.

PyGCMS was performed on both extracted and nonextracted samples. Extraction was performed with ultrasonication using a sequential extraction system essentially the same as used for the biochemical study: $\mathrm{MeOH}$ (3 times) DCM/ $\mathrm{MeOH}$ (1:1) (3 to 10 times, until colorless); DCM (3 times). The pyrolysis system used a CDS pyroprobe with a platinum coil that was inserted directly into the heated $\left(200^{\circ} \mathrm{C}\right)$ injection port of the GC. Pyrolysis occurred for $20 \mathrm{~s}$ at a maximum temperature of $610^{\circ} \mathrm{C}$. GCMS was performed on a Carlo Erba Mega GC, coupled to a Kratos MS-25 mass spectrometer. The GC was fitted with a DB5-fused silica column $(30 \mathrm{~m} \times 0.32$ $\mathrm{mm}$ internal diameter). The column temperature was initially held constant at $40^{\circ} \mathrm{C}$ for $5 \mathrm{~min}$ and then increased to $300^{\circ} \mathrm{C}$ at $5^{\circ} \mathrm{C} / \mathrm{min}$. Electron impact mass spectra (mass range $\mathrm{m} / \mathrm{z} 50$ to 500 ) were acquired at an ionization voltage of $38 \mathrm{eV}$ and an emission current of $400 \mu \mathrm{A}$.

\section{Solid-State ${ }^{13}$ C-NMR}

Whole-round samples were analyzed by solid-state crosspolarization/magic angle spinning (CP/MAS) ${ }^{13} \mathrm{C}-\mathrm{NMR}$ using a
Bruker MSL100 spectrometer. This procedure used an experimental recycle time of $3 \mathrm{~s}$, CP contact time of $1 \mathrm{~ms}$, and decoupling radio-frequency field strength of $60 \mathrm{kHz}$. About 40,000 transients were recorded for each sample, and then Fourier transformed to give a ${ }^{13} \mathrm{C}$-NMR spectrum. Each spectrum was integrated with 165 and 95 ppm as the dividing lines to give the aromaticity value $\left(f_{a}\right)$.

\section{Scanning Electron Microscopy}

\section{Preparation of Samples}

Samples were prepared from wet, cold, but unfrozen, cores. The samples (burial depths, lithologies) are briefly described in Table 2, and the detailed textures and their interpretation are discussed by Kemp and Kearsley (this volume). For each sample, a slab approximately $5 \mathrm{~mm}$ thick was cut from the entire vertical surface of the specimen and stained with osmium tetroxide $\left(\mathrm{OsO}_{4}\right)$ by vapor impregnation of the wet specimen. This generates an osmium metal label on reactive organic matter. Samples were then placed in an ice-cube mold and vacuum-dried for $36 \mathrm{hr}$ in a Logitech 10-20 impregnator. Epotec 301 epoxy resin was vacuum evacuated for $20 \mathrm{~min}$ and then gently released upon the now-dry specimen slab. When returned to atmospheric pressure, the resin successfully impregnated nearly all the pore space and was allowed to cure for $24 \mathrm{hr}$. The impregnated chip was then cut using a Microtec saw, and polished thin sections prepared for electron imagery.

\section{SEM Methodology and Applications}

Polished thin sections were carbon coated and examined in a JSM 840 electron microscope. Backscattered electron imagery (BEI) was employed to produce compositional contrast images of the fine textures. The simple relationship between mineral compositions and gray tones in a backscattered image allows for easy distinction of the differing clastic, bioclastic, cement, and impregnating resin materials. Sedimentary organic matter appears black and is distinguished easily from inorganic components, unless the particle size is smaller than the effective electron-beam interaction volume $(<1 \mu \mathrm{m})$. In this case, osmium-staining can be used. Impregnating resin may be confused with sedimentary organic matter, but the two can be distinguished by the characteristic chlorine content of the resin, using energy dispersive X-ray (EDS) microanalysis. The combined BEI and EDS technique is successful for locating small amounts of organic matter in clay mineral-rich sedimentary rocks. Digital X-ray mapping was used to produce osmium maps that demonstrated the distribution of osmium-reactive organic matter. Test samples of pure inorganic materials (silica, feldspars, sulfides, carbonates, phosphates, and clay minerals) did not react with $\mathrm{OsO}_{4}$ vapor.

Low magnification mosaics were compiled for each sample, providing the basic information for distinction of different lamina types and for the physical isolation of individual laminae for further study. Analyses performed were for total, organic, and carbonate carbon by $\mathrm{CHN}$ analyzer described above; identification of separated foraminifers and diatom species by SEM; complete palynological examination by SEM; and optical microscopy after $\mathrm{HCl} / \mathrm{HF}$ digestion of the laminae.

\section{RESULTS AND DISCUSSION \\ Distribution of Organic Carbon}

\section{Bulk Samples}

The organic-carbon contents of bulk samples (Table 3) show no particular depth trends for any site (Fig. 1). This is 
Table 2. Depth and lithological descriptions for the lamina-scale samples.

\begin{tabular}{|c|c|c|c|}
\hline $\begin{array}{l}\text { Core, section, } \\
\text { interval }(\mathrm{cm})\end{array}$ & $\begin{array}{l}\text { Lith. } \\
\text { Unit }\end{array}$ & Epoch & Lithology \\
\hline $112-680$ B- $1 \mathrm{H}-4,43-45$ & I & Quaternary & $\begin{array}{l}\text { Dark gray, homogeneous, bioturbated silty diatomaceous mud; diatoms of } \\
\text { meroplanktic, upwelling flora; Cyclotella striata, Actinoptychus senarius. } \\
\text { Abundant foraminifers of Bolivina seminuda humilis Assemblage, including } \\
\text { common large Ellipsopolymorphina spp. }\end{array}$ \\
\hline 112-680B-2H-1, 103-105 & I & " & $\begin{array}{l}\text { Finely laminated, alternating } 1-2 \mathrm{~mm} \text { laminae of (1) dark brown, homogenous, } \\
\text { silty diatomaceous mud with common foraminifers, and (2) pale buff } \\
\text { diatom-rich composite laminae (Type I of Kemp and Kearsley, this volume); } \\
\text { diatoms of meroplanktic, upwelling flora: } C \text {. striata, A. senarius, Chaetoceras, } \\
\text { Coscinodiscus cf. radiatus. Foraminifers of } B \text {. seminuda humilis Assemblage: } \\
\text { Cassidella, Nonionella. }\end{array}$ \\
\hline $112-680 \mathrm{~B}-2 \mathrm{H}-4,88-90$ & I & " & $\begin{array}{l}\text { Pale gray silt, rich in quartz, rhyolite and acid volcanic glass grains, coarse } \\
\text { phosphatic fish debris, diatoms of mixed open-ocean and upwelling floras: } \\
\text { Thalassiosira oestrupi, Thalassionema nitzschiodes. }\end{array}$ \\
\hline 112-680B-2H-5, 89-91 & I & " & $\begin{array}{l}\text { Dark olive green laminated diatomaceous mud with thin }(200 \mu \mathrm{m}) \text { silt laminae. } \\
\text { Diatoms of mixed open-ocean and upwelling flora: } T \text {. nitzschiodes parva, } T \text {. } \\
\text { nitzschiodes, Chaeotoceras, A. senarius. Foraminifers of B. seminuda humilis } \\
\text { Assemblage. }\end{array}$ \\
\hline $112-680 \mathrm{~B}-2 \mathrm{H}-6,114-116$ & I & $"$ & $\begin{array}{l}\text { Dark brown, homogeneous diatomaceous mud; diatoms of upwelling flora; } \\
\text { abundant foraminifers of } B \text {. seminuda humilis Assemblage including common } \\
\text { and large Ellipsopolymorphina spp. and Nonionella spp. }\end{array}$ \\
\hline $112-680$ B-2H-6, 116-118 & I & $"$ & $\begin{array}{l}\text { Finely laminated, alternating 1-2 mm laminae of (1) dark olive gray-green } \\
\text { homogeneous clay-rich diatomaceous mud (with abundant foraminifers) and (2) } \\
\text { pale diatom-rich composite laminae (Type I); diatoms of meroplanktic, } \\
\text { upwelling assemblage: A. senarius, Rhizosolenia spp.; foraminifers of } B \text {. } \\
\text { seminuda humilis Assemblage. }\end{array}$ \\
\hline $112-680 \mathrm{~B}-6 \mathrm{H}-7,13-15$ & II & " & $\begin{array}{l}\text { Mid-brown, poorly laminated, diatomaceous mud; dark brown anastomosing, } \\
\text { subvertical veins disrupt fabric; diatoms broken: Thalassiosira oestrupi } \\
\text { open-ocean assemblage; rare formaminifers of } B \text {. seminuda humilis } \\
\text { Assemblage. }\end{array}$ \\
\hline $112-680 \mathrm{~B}-7 \mathrm{H}-3,18-20$ & II & " & $\begin{array}{l}\text { Pale brown and buff poorly-laminated diatom-rich mud; disrupted by dark } \\
\text { gray-green, anastomosing, subvertical veins; diatoms of meroplanktic, } \\
\text { upwelling flora: } A \text {. senarius, Thalassiosira spp.; foraminifers of } B \text {. seminuda } \\
\text { humilis Assemblage rare, partly dissolved. }\end{array}$ \\
\hline $112-680$ B-7H-6, 37-39 & III & Pliocene & $\begin{array}{l}\text { Mid-brown, homogeneous feldspathic silt; poikilotopic gypsum abundant; } \\
\text { diatoms rare: open-ocean assemblage? Foraminifers rare and poorly preserved: } \\
\text { B. seminuda humilis and Nonionella spp. }\end{array}$ \\
\hline $112-680 \mathrm{~B}-9 \mathrm{H}-6,78-80$ & III & " & $\begin{array}{l}\text { Coarsely laminated }(10 \mathrm{~mm}) \text { dark brown and dark gray diatomaceous mud with } \\
100 \mu \mathrm{m} \text { diameter pellets, fabric disrupted by dark brown anastomosing veins. } \\
\text { Poikilotopic gypsum abundant; diatoms of meroplanktic, upwelling } \\
\text { assemblage, A. senarius; foraminifers lost by dissolution. }\end{array}$ \\
\hline $112-680 \mathrm{~B}-10 \mathrm{H}-5,50-52$ & III & $"$ & $\begin{array}{l}\text { Finely laminated, alternating } 1-2 \mathrm{~mm} \text { laminae of (1) mid to dark olive gray-green, } \\
\text { clay and silt-rich diatomaceous mud and (2) pale gray-green diatom-rich } \\
\text { composite laminae (Type I). Diatoms of meroplanktic, upwelling flora: } A \text {. } \\
\text { senarius, } T \text {. nitzchioides, Nitzschia spp., Delphineis spp.; foraminifers partially } \\
\text { dissolved, only poorly preserved } B \text {. seminuda humilis and organic inner walls. }\end{array}$ \\
\hline
\end{tabular}

more apparent when looking at trends within the same sediment unit. For example, there is no systematic increase or decrease for the top six samples from Hole 679D, nor the top five samples from Hole 680B (all from lithologic Unit I: Table 1). This suggests that the variation is related primarily to conditions prevailing at the time of sediment deposition, rather than diagenetic effects. This idea is enforced by the observed variation in organic-carbon contents for surface samples from site to site. In particular, organic-carbon contents tend to be lower at Sites 681 and 686 than at Sites 679 and 680 (Table 3). Similar wide variations in organic carbon content of the Peru upwelling region sediments were noted previously (Poutanen and Morris, 1983 and references therein).

\section{Lamina-Scale Samples}

Most of the samples studied were olive gray-green or dark brown, laminated diatomaceous muds (described more completely by Kemp and Kearsley, this volume). A summary of the general lithology for each of the samples is given in Table 2.

Results of the textural, chemical, and micropaleontological characterizations of the individual laminae for each of the laminated samples and those results for single representative samples of the unlaminated samples are shown in Table 4.
Individual laminae of the shallow samples $(<15 \mathrm{~m})$ alternated between (1) dark, low porosity, clay-(and scattered silt-)rich diatomaceous muds containing abundant diatom debris and foraminifer tests, a relatively high percentage of organic-carbon and moderate diagenetic carbonate content; and (2) pale, high porosity, clay-poor diatom "framework" oozes containing a high proportion of complete, well-preserved articulated diatom frustules, moderate organic-carbon contents, and slightly higher diagenetic carbonate contents.

Both lithologies present in the laminated samples contain a diatom flora of predominantly meroplanktic upwelling centric diatoms comparable to those described by Schuette and Schrader (1979), Whiting and Schrader (1985), and Uribe et al. (1982). Characteristic taxa include Cyclotella striata, Actinoptychus senarius, oval Delphineis spp., Chaetoceros bristles and spores, Thalassiosira of the eccentrica group, elongate Thalassionema nitzschioides, and diverse Rhizosolenia spp.

The characteristic foraminiferal fauna seen throughout all the samples studied is the Bolivina seminuda humilis assemblage, which denotes an outer-shelf, upper bathyal oxygenminimum zone similar to the interpretation of Funnell et al. (this volume). Characteristic taxa include dominant Bolivina 
Table 3. Elemental composition of the bulk samples.

\begin{tabular}{|c|c|c|c|c|c|c|c|c|c|c|c|c|c|c|c|c|}
\hline \multirow{2}{*}{$\begin{array}{l}\text { Core, section, } \\
\text { interval }(\mathrm{cm})\end{array}$} & \multirow{2}{*}{$\begin{array}{l}\mathrm{HCl} \\
\text { Sol }\end{array}$} & \multicolumn{15}{|c|}{ Elemental composition ${ }^{\mathrm{a}}$ (wt \%) } \\
\hline & & $\mathrm{C}_{\text {org }}$ & $\mathrm{H}$ & $\mathrm{O}_{\text {org }}$ & $\mathrm{O}_{\text {inorg }}$ & $\mathbf{N}$ & $\mathrm{S}$ & $\mathrm{Na}$ & $\mathrm{Mg}$ & $\mathrm{Al}$ & $\mathrm{Si}$ & $\mathrm{Cl}$ & $\mathbf{K}$ & $\mathrm{Ca}$ & $\mathrm{Ti}$ & $\mathrm{Fe}$ \\
\hline 112-679D-1-1, 25-35 & 35.8 & 10.3 & 1.2 & 5.0 & 18.5 & 1.2 & 0.9 & 1.0 & 0.4 & 4.4 & 17.3 & 0.5 & 1.5 & 1.0 & 0.1 & 0.8 \\
\hline $112-679 D-1-1,73-83$ & 18.5 & 5.9 & 0.7 & 4.8 & 29.6 & 0.9 & 1.1 & 1.5 & 0.7 & 6.4 & 23.6 & 0.3 & 2.6 & 1.1 & 0.5 & 1.4 \\
\hline $112-679-1-2,131-141$ & 21.5 & 7.1 & 0.9 & 5.4 & 27.4 & 0.9 & 1.5 & 1.6 & 0.7 & 6.4 & 21.2 & 0.7 & 2.4 & 0.7 & 0.2 & 1.4 \\
\hline 112-679D-1-4, 88-98 & 28.1 & 12.7 & 1.4 & 5.9 & 18.7 & 1.2 & 2.2 & 1.4 & 0.5 & 5.0 & 18.7 & 0.6 & 1.7 & 0.7 & 0.1 & 1.1 \\
\hline $112-679 D-2-2,48-58$ & 18.5 & 10.9 & 1.4 & 6.0 & 26.4 & 1.0 & 2.5 & 1.1 & 0.6 & 5.8 & 20.4 & 0.9 & 2.1 & 1.0 & 0.2 & 1.2 \\
\hline $112-679 D-5-2,111-123$ & 27.7 & 2.9 & 0.6 & 3.5 & 27.8 & 0.3 & 1.7 & 0.9 & 0.7 & 4.8 & 24.6 & 0.2 & 2.0 & 0.9 & 0.1 & 1.3 \\
\hline $112-679 \mathrm{D}-9-1,59-71$ & 12.0 & 6.2 & 1.0 & 4.9 & 30.6 & 0.5 & 2.8 & 1.2 & 0.8 & 4.5 & 30.8 & 0.3 & 1.5 & 1.1 & 0.1 & 1.7 \\
\hline 112-679D-17X-1, 108-116 & 15.3 & 0.6 & 0.2 & 2.5 & 38.1 & 0.3 & 1.4 & 2.4 & 0.8 & 5.5 & 27.1 & 0.0 & 2.0 & 1.8 & 0.3 & 1.6 \\
\hline 112-679D-12X-1, 88-96 & 18.4 & 2.4 & 0.5 & 3.4 & 30.9 & 0.1 & 2.6 & 1.1 & 1.1 & 6.0 & 28.6 & 0.0 & 1.7 & 0.5 & 0.2 & 2.5 \\
\hline 112-680B-1-1, 29-41 & 32.2 & 11.0 & 1.4 & 5.8 & 18.7 & 1.0 & 1.2 & 0.7 & 0.5 & 4.2 & 19.7 & 0.8 & 1.4 & 0.4 & 0.2 & 0.8 \\
\hline $112-680 \mathrm{~B}-1-1,70-82$ & 38.3 & 9.0 & 1.1 & 4.6 & 18.2 & 0.8 & 1.1 & 0.7 & 0.4 & 3.7 & 19.1 & 0.6 & 1.2 & 0.4 & 0.1 & 0.7 \\
\hline $112-680 \mathrm{~B}-1-4,26-34$ & 26.2 & 5.0 & 0.7 & 3.8 & 27.5 & 0.4 & 1.6 & 1.0 & 0.6 & 4.4 & 25.8 & 0.0 & 1.4 & 0.5 & 0.1 & 1.0 \\
\hline $112-680 \mathrm{~B}-2-3,29-37$ & 28.6 & 6.1 & 0.9 & 4.1 & 22.6 & 0.4 & 2.5 & 1.0 & 0.6 & 4.4 & 24.3 & 1.0 & 1.7 & 0.6 & 0.1 & 1.1 \\
\hline $112-680 \mathrm{~B}-3-5,129-139$ & 27.1 & 8.5 & 1.2 & 4.2 & 23.0 & 0.4 & 3.2 & 0.9 & 0.4 & 3.4 & 24.0 & 0.8 & 1.2 & 0.7 & 0.1 & 0.9 \\
\hline $112-680 \mathrm{~B}-10-6,88-100$ & 11.5 & 1.9 & 0.5 & 3.9 & 33.4 & 0.1 & 2.9 & 1.3 & 1.1 & 6.7 & 30.1 & 0.4 & 2.4 & 0.6 & 0.4 & 2.3 \\
\hline $112-681 \mathrm{~B}-1-1,36-44$ & 23.4 & 5.1 & 0.8 & 4.6 & 28.7 & 0.5 & 1.1 & 0.9 & 0.6 & 4.0 & 26.8 & 0.5 & 1.3 & 0.5 & 0.2 & 1.0 \\
\hline $112-681 \mathrm{~B}-1-1,81-89$ & 19.0 & 4.0 & 0.6 & 3.2 & 32.7 & 0.3 & 1.0 & 1.4 & 0.6 & 5.5 & 27.5 & 0.0 & 1.9 & 1.0 & 0.2 & 1.1 \\
\hline $112-681 \mathrm{~B}-2-2,83-91$ & 29.6 & 2.4 & 0.4 & 3.0 & 33.0 & 0.1 & 1.5 & 1.0 & 0.6 & 3.9 & 21.1 & 0.3 & 1.3 & 0.6 & 0.1 & 1.1 \\
\hline $112-681 \mathrm{~B}-2-5,34-42$ & 17.3 & 1.6 & 0.4 & 3.2 & 33.6 & 0.1 & 2.3 & 1.1 & 0.7 & 4.0 & 32.2 & 0.2 & 1.5 & 0.4 & 0.2 & 1.2 \\
\hline $112-681 \mathrm{~B}-5-5,57-69$ & 37.5 & 2.6 & 0.6 & 3.2 & 20.7 & 0.2 & 1.4 & 0.7 & 0.6 & 2.2 & 27.5 & 0.2 & 0.8 & 0.2 & 0.1 & 0.8 \\
\hline $112-681 \mathrm{~B}-10-2,120-131$ & 28.3 & 4.0 & 0.6 & 3.3 & 23.3 & 0.3 & 1.7 & 1.3 & 1.0 & 6.5 & 24.4 & 0.0 & 2.6 & 0.6 & 0.3 & 1.8 \\
\hline $112-681 \mathrm{~B}-13 \mathrm{X}-5,100-112$ & 28.2 & 2.9 & 0.6 & 3.4 & 25.4 & 0.2 & 1.9 & 0.8 & 0.6 & 3.4 & 30.0 & 0.0 & 1.3 & 0.2 & 0.1 & 1.0 \\
\hline $112-686 \mathrm{~B}-1-1,30-39$ & 16.1 & 3.4 & 0.7 & 4.2 & 31.1 & 0.6 & 1.3 & 1.8 & 1.0 & 6.4 & 27.7 & 0.0 & 2.5 & 1.3 & 0.3 & 1.6 \\
\hline $112-686 \mathrm{~B}-1-1,87-96$ & 13.9 & 1.8 & 0.4 & 3.0 & 34.6 & 0.4 & 1.5 & 2.0 & 1.0 & 6.5 & 28.4 & 0.0 & 2.5 & 1.9 & 0.3 & 1.8 \\
\hline $112-686 \mathrm{~B}-1-3,79-89$ & 15.5 & 4.4 & 0.7 & 4.0 & 34.0 & 0.6 & 1.9 & 1.8 & 0.8 & 5.4 & 26.2 & 0.0 & 2.2 & 1.1 & 0.3 & 1.4 \\
\hline $112-686 \mathrm{~B}-1-5,80-90$ & 20.3 & 1.3 & 0.2 & 1.8 & 33.3 & 0.2 & 1.1 & 2.5 & 0.9 & 6.5 & 25.5 & 0.0 & 2.3 & 2.2 & 0.3 & 1.6 \\
\hline $112-686 \mathrm{~B}-3-2,33-45$ & 25.3 & 1.8 & 0.4 & 3.4 & 27.9 & 0.4 & 1.8 & 1.6 & 1.0 & 5.3 & 26.1 & 0.0 & 2.0 & 1.0 & 0.3 & 1.7 \\
\hline $112-686 \mathrm{~B}-9 \mathrm{X}-5,30-44$ & 12.3 & 2.5 & 0.5 & 3.9 & 35.1 & 0.4 & 1.5 & 2.0 & 0.9 & 5.1 & 30.7 & 0.3 & 1.9 & 1.3 & 0.2 & 1.4 \\
\hline $112-686 \mathrm{~B}-15 \mathrm{X}-5,32-42$ & 13.5 & 4.7 & 0.8 & 4.8 & 31.9 & 0.6 & 1.8 & 1.4 & 0.8 & 5.0 & 29.4 & 0.5 & 1.7 & 1.3 & 0.2 & 1.6 \\
\hline
\end{tabular}

${ }^{a} \mathrm{HCl}$ sol indicates sediment soluble in cold $6 \mathrm{~mol} / \mathrm{L} \mathrm{HCl}$ (e.g., carbonate, phosphate, chloride). Abundances of individual elements do not include any species soluble in $6 \mathrm{~mol} / \mathrm{L} \mathrm{HCl}$. $\mathrm{O}_{\text {org }}=$ pyrolyzable oxygen (organic $\mathrm{O}$ plus $\mathrm{H}_{2} \mathrm{O}$ plus ?), $\mathrm{O}_{\text {inorg }}=$ total oxygen less $\mathrm{O}_{\text {org }}$ (mainly silicates). Elemental composition is normalized to $100 \%$.

seminuda humilis, Cassidella spp., Nonionella $\mathrm{cf}$. miocenica, and Ellipsopolymorphina spp.

The palynological assemblage from the laminated samples is massively dominated by fine aggregates of "amorphous" organic matter. There are also common organic coatings on framboidal sulphides and scattered smooth dinoflagellate cysts of the Brigantedinium group, tintinnid loricae, and well-preserved foraminiferal organic wall linings, including thin-walled Cassidella spp. (Fig. 2). This assemblage contains no observable terrigenous influx of either vascular or reproductive materials, and is thus similar to that noted throughout the Quaternary sequence, as described by Dodge et al. (this volume).

The organic-carbon contents of the diatom framework laminae tend to be lower than those of the lower porosity, clay-rich mud laminae (Table 4). This is more clearly demonstrated by the mosaic from Sample 112-680A-2H-1, 103-105 $\mathrm{cm}$ (Fig. 3; Table 5). This mosaic shows that higher organiccarbon content occurs in the laminae having lower porosity and vice versa. This is at first sight puzzling, because diatoms are largely organic and thus the diatom-rich layers potentially have a higher organic influx. Possibly this indicates that large amounts of organic carbon are also supplied to the sediment associated directly with the clays. Alternatively, it may be the result of differential preservation of organic material. The potentially higher organic influx to the diatom-dominant layer may be subject to a greater degree of microbial degradation and remobilization owing to the much greater (up to $60 \%$ ) porosity of the framework. The apparent inverse relationship of nonbioclastic carbonate to organic-carbon content (i.e., low organic-carbon-content laminae tend to have higher carbonate percentages; Tables 5 and 6 ) also suggests biological conver- sion of organic carbon to carbonate, with the process being controlled on a lamina-scale, and progressing further in the framework. Diagenetic sulfide, predominantly in the form of pyrite, is not abundant in these laminae, which would encourage carbonate precipitation during bacterial sulfate reduction (Coleman, 1985). Stable isotope studies of the carbonate and detailed geochemical analysis of the residual organic carbon should help to confirm this.

In contrast to the above mosaic, laminated Sample 112680B-10H-5, 50-52 cm (Fig. 4) contains low organic-carbon contents and low carbonate (Table 6). However, diagenetic sulfide is abundant in these samples, probably because more $\mathrm{Fe}^{2+}$ was available, associated with the higher clay content. Pyrite precipitation during sulphate reduction may have been sufficient to tip the carbonate equilibrium toward dissolution, rather than precipitation, as observed in the shallower samples (Coleman, 1985). The few poorly preserved foraminifers present show partial dissolution of the carbonate test. Figure 5 shows the effect of this dissolution on the thick-walled Bolivina spp. Voids and the remains of the partially dissolved tests indicate the initial presence of a typical $B$. seminuda humilis assemblage, but with destruction of calcite following burial. Although the carbonate of the test may be completely dissolved, the organic inner test wall is sometimes preserved (Fig. 5C).

Sample $112-680 \mathrm{~A}-2 \mathrm{H}-1,103-105 \mathrm{~cm}$, is from lithologic Unit I, of Quaternary age, from a sequence having an estimated mean deposition rate of $55 \mathrm{~m} / \mathrm{m} . \mathrm{y}$., whereas Sample $112-680 \mathrm{~B}-10 \mathrm{H}-5,50-52 \mathrm{~cm}$, is from lithologic Unit III, Pliocene age and from a sequence with a deposition rate of about 22 to $30 \mathrm{~m} / \mathrm{m}$.y. (Suess, von Huene, et al., 1988). It seems possible that the low organic-carbon content and loss of 

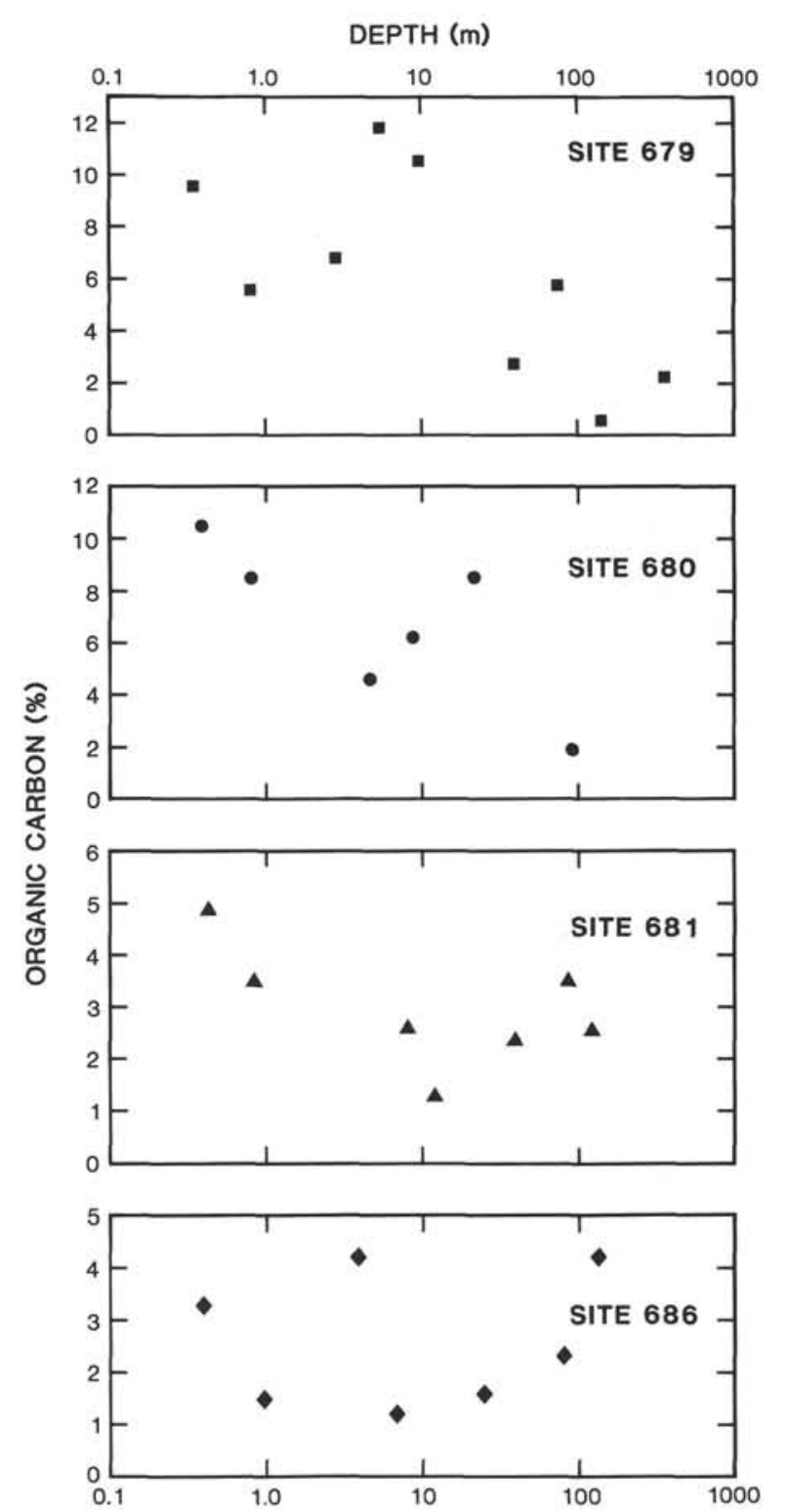

Figure 1. Variations in organic-carbon content with depth for bulk samples.

carbonate in the $112-680 \mathrm{~B}-10 \mathrm{H}-5$ samples reflect prolonged sulfate diffusive access to the sediment (as a consequence of low sedimentation rate) and therefore more extensive bacterial oxidation in the sulfate reduction zone (Coleman, 1985). Changes in organic composition associated with this contrast in diagenetic regime will be investigated.

Samples 112-680B-2H-4, 88-90 cm, and 112-680B-7H-6, $37-39 \mathrm{~cm}$, are pale, silty, and feldspathic unlaminated samples. These samples reflect low-density bottom current (turbidity flow?) deposition of terrigenous volcanic materials (Scheidegger and Krissek, 1982; Yerino and Maynard, 1984). They contain low organic-carbon and carbonate contents (Table 4) and have a diatom flora of predominantly nonupwelling type with abundant Thalassiosira oestrupi. Rare fragments of vascular plant tissue are also present. Foraminiferal faunas are sparse, possibly owing to rapid deposition. However, the fauna present indicates a B. seminuda humilis dysaerobic assemblage.

\section{Composition of Organic Matter}

\section{Elemental Analysis}

The elemental compositions of bulk samples from four sites $(679,680,681$, and 686) were determined, with the exception of material that was soluble in concentrated $\mathrm{HCl}$. (This is presented simply as " $\mathrm{HCl}$ soluble" in Table 3.) From these analyses, the elemental compositions of the organic matter were deduced; these are discussed below. However, most of each sediment is inorganic, and its composition is mentioned briefly first. The $\mathrm{HCl}$-soluble material represents between $12 \%$ and $38 \%$ of the total sediment weight. The major elements (by weight) in the remaining, $\mathrm{HCl}$-insoluble sediments are "inorganic" oxygen and silicon (presumably as silica/silicates), which together constitute a further $35 \%$ to $65 \%$ of the total. These inorganic substances are followed in abundance by organic carbon (typically $2 \%$ to $12 \%$ ), "organic" oxygen (which includes water bound onto silica) ( $2 \%$ to $6 \%$ ), and aluminum ( $2 \%$ to $6 \%$ ). There are lesser amounts $(0.5 \%$ to $3 \%)$ of hydrogen, nitrogen, sulfur, calcium, potassium, and iron. All these data confirm that the sediments are organic-rich, silica-rich, and clastic-poor. The inorganic constituents of the sediments are considered in more detail by Mossman et al. (this volume).

Five ratios of elements, which are main constituents of the organic matter, were calculated to investigate its nature and diagenesis. These were hydrogen/organic-carbon $\left(\mathrm{H} / \mathrm{C}_{\mathrm{org}}\right)$, "organic" oxygen/organic-carbon $\left(\mathrm{S} / \mathrm{C}_{\mathrm{org}}\right)$ and organic-sulfur/ organic-carbon $\left(\mathrm{S}_{\mathrm{org}} / \mathrm{C}_{\text {org }}\right.$ ) (Table 7). A plot of $\mathrm{H} / \mathrm{C}_{\text {org }}$ vs. $\mathrm{O}_{\text {org }} / \mathrm{C}_{\text {org }}$ (a van Krevelen-type diagram) for all samples (Fig. 6) demonstrates that a strong linear correlation exists between these two ratios, but that absolute values are so high that all the hydrogen and oxygen cannot be organic. Clearly, there is water still associated with the samples (presumably bound onto the silica), despite the fact that the samples were freezedried. However, the lowest $\mathrm{H} / \mathrm{C}_{\text {org }}(1.36)$ and $\mathrm{O}$. . org." $/ \mathrm{C}_{\text {org }}(0.35)$ ratios are associated with the highest $\% \mathrm{C}_{\text {org }}$ sediments, and it seems reasonable to suppose that these values are approaching true ratios for the organic matter alone. This approach does not allow one to pick out any changes in organic $\mathrm{H} / \mathrm{C}$ or $\mathrm{O} / \mathrm{C}$ with depth or from site to site, although from Figure 6 it appears that these changes are unlikely to be large.

Individual organic $\mathrm{O} / \mathrm{C}$ ratios for four samples from Site 680 were determined from solid-state ${ }^{13} \mathrm{C}-\mathrm{NMR}$ data (Table 8 ). This technique provides data for the amount (wt.\%) of organic-carbon attached to three oxygen-containing functional groups $(\mathrm{C}=\mathrm{O}, \mathrm{COOR}$, and $\mathrm{C}-\mathrm{O})$. The weight percent of oxygen in the organic matter can be estimated by assuming that (1) in $\mathrm{C}=\mathrm{O}$ groups one carbon atom is attached to one oxygen atom, (2) in COOR groups one carbon atom is attached to two oxygen atoms, and (3) in C-O groups, two carbon atoms are attached to one oxygen atom (this is true when $\mathrm{C}-\mathrm{O}$ represents an ether, but is not true when $\mathrm{C}-\mathrm{O}$ is a hydroxyl). Atomic $\mathrm{O} / \mathrm{C}$ ratios thus calculated vary from 0.30 to 0.37 (Table 8 ), which, allowing for experimental error, are not statistically different from the value of 0.35 obtained from extrapolation of the elemental analysis data (Fig. 6). Individual $\mathrm{O} / \mathrm{C}$ results from NMR for Site 680 (Table 8) suggest that no pronounced change occurs in organic $\mathrm{O} / \mathrm{C}$ with depth in these sediments. This confirmation of the extrapolated $\mathrm{O} / \mathrm{C}$ value from elemental analysis supports the validity of the organic $\mathrm{H} / \mathrm{C}$ ratio (1.36) obtained in the same manner. These two average values for organic matter classify the ODP samples as "immature type II" on a van Krevelen diagram. 
Table 4. Lithologies and carbon contents of the lamina-scale samples.

\begin{tabular}{|c|c|c|c|c|c|c|}
\hline $\begin{array}{l}\text { Core, section } \\
\text { interval }(\mathrm{cm})\end{array}$ & $\begin{array}{l}\text { Depth } \\
\text { (mbsf) }\end{array}$ & $\begin{array}{l}\text { Sub- } \\
\text { sample }\end{array}$ & $\begin{array}{c}\mathrm{C}_{\text {total }} \\
(\%)\end{array}$ & $\begin{array}{l}\mathrm{C}_{\text {org }} \\
(\%)\end{array}$ & $\begin{array}{c}\text { Carbonate } \\
(\%)\end{array}$ & Lithology \\
\hline $112-680 \mathrm{~B}-1 \mathrm{H}-4,43-45$ & 4.93 & & 7.2 & n.d. & n.d. & Dark brown homogeneous diatom mud. \\
\hline \multirow[t]{4}{*}{$112-680 \mathrm{~A}-2 \mathrm{H}-1,103-105$} & 9.33 & A & 8.4 & 6.4 & 9.8 & Dark brown homogeneous diatom mud. \\
\hline & & B & 6.5 & 3.7 & 13.8 & Pale buff laminated diatom framework. \\
\hline & & $\mathrm{C}$ & 7.1 & 5.4 & 8.7 & Mid-brown laminated diatom framework. \\
\hline & & D & 8.3 & 6.7 & 8.2 & Dark brown poorly laminated mud. \\
\hline $112-680 \mathrm{~B}-2 \mathrm{H}-4,88-90$ & 10.88 & G & 1.4 & 1.2 & 0.78 & Pale gray silt. \\
\hline $112-680 \mathrm{~B}-2 \mathrm{H}-5,89-91$ & 12.39 & G & 4.4 & n.d. & n.d. & Dark olive green laminated diatom mud. \\
\hline $112-680 \mathrm{~B}-2 \mathrm{H}-6,114-116$ & 14.14 & G & 9.9 & n.d. & n.d. & Dark brown homogeneous diatom mud. \\
\hline \multirow[t]{5}{*}{$112-680 \mathrm{~B}-2 \mathrm{H}-6,116-118$} & 14.16 & A & 7.3 & 5.1 & 10.6 & Pale olive green diatom framework. \\
\hline & & $\mathrm{B}$ & 7.7 & 5.4 & 11.4 & Mid-olive green diatom mud. \\
\hline & & $\mathrm{C}$ & 6.6 & 4.6 & 10.2 & Dark olive green diatom mud. \\
\hline & & D & 8.1 & 6.1 & 10.2 & Pale to mid-olive green diatom mud. \\
\hline & & $\mathrm{E}$ & 9.1 & 7.3 & 9.1 & Dark olive green diatom mud. \\
\hline \multirow[t]{2}{*}{$112-680 \mathrm{~B}-6 \mathrm{H}-7,13-15$} & 52.63 & A & 5.6 & n.d. & n.d. & Dark brown vein. \\
\hline & & B & 5.4 & n.d. & n.d. & Mid-brown laminated diatom mud. \\
\hline \multirow[t]{2}{*}{$112-680 \mathrm{~B}-7 \mathrm{H}-3,18-20$} & 56.18 & A & 3.7 & n.d. & n.d. & Pale buff laminated diatom rich mud. \\
\hline & & B & 4.8 & n.d. & n.d. & Dark gray-green vein. \\
\hline $112-680 \mathrm{~B}-7 \mathrm{H}-6,37-39$ & 69.37 & $\mathrm{G}$ & 1.0 & n.d. & n.d. & Mid-brown homogeneous feldspathic silt. \\
\hline \multirow[t]{2}{*}{$112-680$ B- 9 H- $6,78-80$} & 80.28 & A & 1.4 & n.d. & n.d. & Dark gray-green vein. \\
\hline & & B & 0.6 & n.d. & n.d. & $\begin{array}{l}\text { Mid-gray-green homogeneous diatom } \\
\text { mud. }\end{array}$ \\
\hline \multirow{5}{*}{$112-680 \mathrm{~B}-10 \mathrm{H}-5,50-52$} & 88.00 & A & 1.8 & 1.7 & 0.56 & Dark olive green diatom framework. \\
\hline & & B & 1.7 & 1.6 & 0.36 & Mid-olive green diatom mud. \\
\hline & & $\mathrm{C}$ & 1.6 & 1.5 & 0.21 & $\begin{array}{l}\text { Pale } \rightarrow \text { dark olive green pelleted diatom } \\
\text { framework. }\end{array}$ \\
\hline & & D & 1.4 & 1.3 & 0.27 & $\begin{array}{l}\text { Banded mid and pale olive green diatom } \\
\text { framework. }\end{array}$ \\
\hline & & $\mathrm{E}$ & 1.8 & 1.7 & 0.54 & Dark olive green diatom framework. \\
\hline
\end{tabular}

n.d. $=$ Not determined.

Atomic N/C $\mathrm{C}_{\text {org }}$ ratios decline with depth in Holes 679D and $680 \mathrm{~B}$ (Table 7); in Holes $681 \mathrm{~B}$ and $686 \mathrm{~B}$, there is no clear trend with depth, although samples from within the same unit do decline (e.g., Unit I in Hole 681B: Table 1). In Hole 680B, values decline from approximately 0.08 at the surface to 0.04 at $22.39 \mathrm{~m}$ (Fig. 7). (Note that the nitrogen concentration is for total, nonacid leachable, nitrogen, i.e., potentially organic and inorganic. Any significant inorganic contribution is unlikely, since nitrogen concentrations were determined after $\mathrm{HCl}$ extraction, which would remove ammonium or nitrate-bearing salts. Confirmation of this was provided by X-ray photoelectron spectroscopy, which did not detect any inorganic nitrogen. Thus the $\mathrm{N} / \mathrm{C}_{\text {org }}$ ratio is that of the organic matter.)

Variations in $N / C_{\text {org }}$ with depth have been used in the literature to indicate the origin and extent of degradation of organic matter as a whole (e.g., Walsh et al., 1981). The surface ratios examined here are typical of marine sediments (Stevenson and Cheng [1972] reported typical atomic $\mathrm{N} / \mathrm{C}_{\text {org }}$ values of 0.05 to 0.09 in Argentine Basin sediments, for example). These values are lower than the Redfield ratios for marine plankton $(\mathrm{C} / \mathrm{N}=5.7$ by weight; $\mathrm{N} / \mathrm{C}$ atomic $=0.15$ : Mueller et al., 1986) and are suggestive of organic matter degradation. An exception is at Site 686, where two surface $(<1 \mathrm{~m})$ values were measured at 0.15 and 0.19 (Table 7 ). Further decrease in $\mathrm{N} / \mathrm{C}_{\text {org }}$ ratios with depth at Sites 679 and 680 is an indication of microbial degradation during burial and that organic nitrogen is being metabolized more rapidly than organic carbon (Rosenfeld, 1979). Again, Site 686 is an exception; samples show no decrease in N/C ratios with depth, perhaps an indication that little organic matter is metabolized before or after sedimentation at this site. Possibly this is related to the faster sedimentation rate in these sediments.

Conversely to the N/C results, $\mathrm{S}_{\text {org }} / \mathrm{C}_{\text {org }}$ increases at Site 680B (Fig. 7-data from Mossmann et al., this volume) and $\mathrm{S} / \mathrm{C}_{\text {org }}$ generally increases at Sites $680 \mathrm{~B}, 679 \mathrm{D}$, and $681 \mathrm{~B}$ (Table 7). As with the trend for $\mathrm{N} / \mathrm{C}_{\text {org }}$, Site $686 \mathrm{~B}$ does not show any clear trend for $\mathrm{S} / \mathrm{C}_{\text {org }}$ (Table 7$)$. Nevertheless, all these data support the concept of very early sulfurization of the sediment as a whole and the organic matter in particular. Mossmann et al. (this volume) discuss this subject at greater length.

\section{Biochemical Analyses}

The composition of a living organism is frequently presented in terms of its lipid, carbohydrate, and protein contents. These are components having reasonably well-defined chemical structures, at least in general terms. Proteins are composed of (via amide linkages) a limited number (20) of main amino acids, the structures of which are all known. Carbohydrates (polysaccharides) are formed from a smaller number of sugars (monosaccharides) having the general formula, $\mathrm{CH}_{2} \mathrm{O}$. Lipids are less well-defined chemically, as their definition is physical, namely solubility in an organic solvent. However, the term is used ubiquitously to cover a wide range of structures, which have in common the fact that they are hydrocarbons with or without a functional group (typically containing oxygen) in the molecule (e.g., sterols, fatty acids, alkanes). These three biochemical terms have been taken and applied to the total organic matter in the sediments. "Protein" is used to refer to both free (water-soluble) proteins and amino acids, as well as amino acids released only by acid hydrolysis (bound). "Carbohydrate" is used in an identical fashion to cover mono- and polysaccharides. "Lipid" is used according to its biochemical definition; free lipids are solvent-soluble, and bound lipids are soluble after base hydrolysis.

The sedimentary protein contribution to the total $\mathrm{C}_{\text {org }}$ declines with depth from about $17 \%$ to $5 \%$ for Hole $680 \mathrm{~B}$ (Table 9, Fig. 8). This is in agreement with the decline in the $\mathrm{N} / \mathrm{C}_{\text {org }}$ ratio (Table 7 , Fig. 7) and supports our assertion that the change in the latter results from a decrease in the abundance of organic nitrogen and that this organic nitrogen is tied up mainly in amide linkages. The bulk of the proteins is present as "bound" material, i.e., it is water-insoluble but $\mathrm{HCl}$-hydrolyzable. Approximately $45 \%$ of the total nitrogen in 

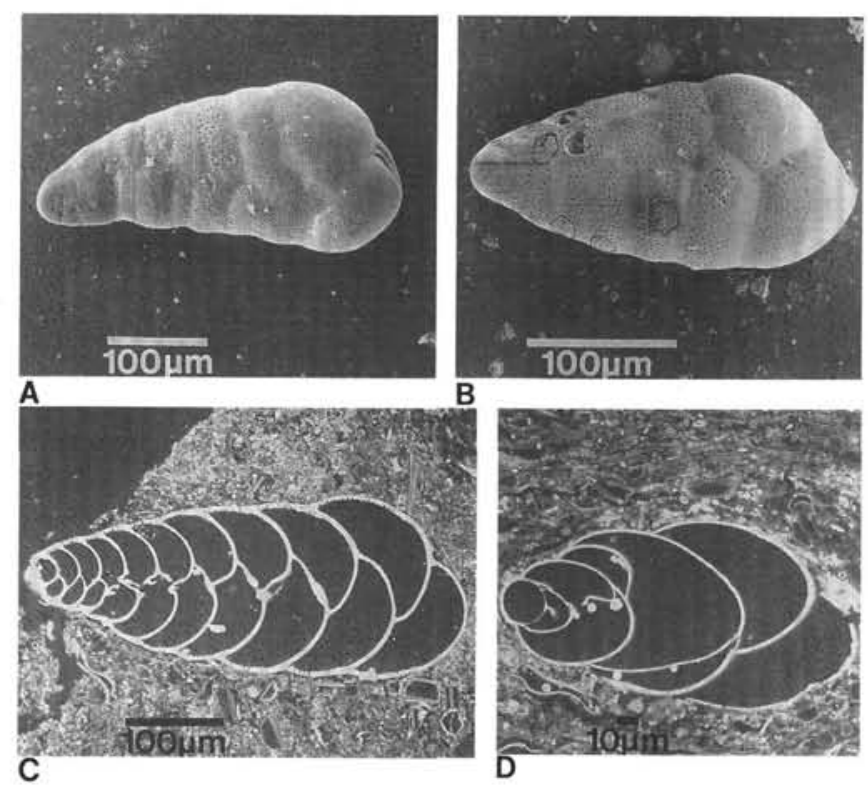

B

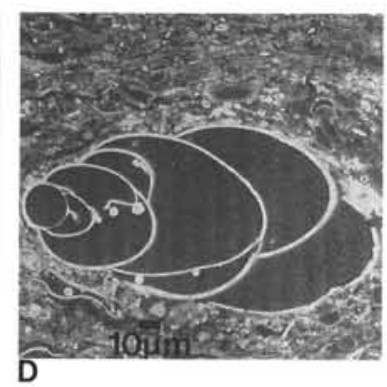

Figure 2. Secondary electron images. A. Well-preserved B. seminula humilis $(200 \times)$. B. As in A, except with circular dissolution rings $(300 \times)$. C. BEIs of (A) section through well-preserved $B$. seminula humilis (note thick calcite wall) $(200 \times)$. D. Well-preserved Cassidella sp. (note thin calcite wall) $(400 \times)$. All from mosaic of Sample $112-680 \mathrm{~A}-2 \mathrm{H}-1,103-105 \mathrm{~cm}$.

the surface sediments is present in proteins, compared with about $25 \%$ in the two deepest samples. These values are comparatively large for aquatic sediments (see data summarized in Whelan, 1977), but they are similar to the $40 \%$ to $70 \%$ range for surface sediments from the Peru region calculated by Henrichs and Lee (1984).

There is a similar decrease in the abundance of carbohydrates, from over $8 \%$ of the organic carbon at the surface to $3.5 \%$ at $22.39 \mathrm{~m}$ (Table 9, Fig. 8). Again, the bulk of this biochemical class is present in a "bound" form. Although carbohydrates contain more oxygen than other biochemical classes (general formula $=\mathrm{CH}_{2} \mathrm{O}$ ), there is no indication that their decreased abundance accompanies a decrease in the organic $\mathrm{O} / \mathrm{C}$ ratio calculated from NMR data (Table 8 ). This suggests that other fractions (i.e., the lipids or the biochemically uncharacterized fraction) must have $\mathrm{O} / \mathrm{C}$ ratios near the value for the whole (i.e., 0.35). The abundance of the total lipids also decreases with depth (Table 9, Fig. 8). In this case, roughly $30 \%$ to $40 \%$ of the total lipid is defined as "free" (i.e., no hydrolysis is required before extraction), which is much higher than for the carbohydrates or proteins. The general decrease in lipid content is reversed by the increase in the deepest sample (112-680B-10H-6); this sample is in a different sediment unit (Table 1) and thus it may not be reasonable to compare it with the five shallower samples. One must also remember that the two most shallow samples are from a burial depth of less than $1 \mathrm{~m}$; in view of the drilling disturbance in the top meter, and the nature of these samples ("soupy mud"), we do not find it realistic to interpret differences in results for samples from 0.41 and $0.82 \mathrm{~m}$ in terms of diagenetic causes. The general decrease in all three biochemical classes with depth (from about $60 \%$ of the total organic carbon at the surface, decreasing to about $20 \%$ at $22 \mathrm{~m}$; Table 9) is in close agreement with diagenetic trends reported for other marine sediments (Romankevich, 1984) for amino acids (Brown et al., 1972) sugars (Vallen- tyne, 1963) and total (HCl) hydrolyzable organics (Huc et al., 1978).

\section{Geochemical Analysis}

Two basic geochemical parameters were calculated from a combination of the percentage of $\mathrm{C}_{\text {org }}$ and pyrolysis data. Hydrogen indexes $\left(\mathrm{HI}=100 . \mathrm{S}_{2} / \% \mathrm{C}_{\mathrm{org}}\right)$ vary from 280 to 450 over the four sites (Table 10). The major difference arises from the lower values obtained for samples from Site 686 (280 to $330)$. For the other three sites $(679,680$, and 681$)$, values range from 300 to 450 , although most samples fall between 350 and 400 . The reason for the lower values at Site 686 is not clear. In general, Site 686 sediments have a higher contribution from terrigenous material, as evidenced by higher iron, aluminum, potassium, calcium, and sodium levels (Table 3 ), and this may also be true of the organic matter. Lower HI values may be a reflection of this, plus the lack of sediment microbial reworking indicated by the constancy of N/C ratios with depth (Table 7). Gas/oil ratios (the ratio of $\mathrm{C}_{1-5} / \mathrm{C}_{6}$ components, or "GOGI") determined from pyGC vary between 0.19 and 0.28 , with no obvious intersite differences (Table 10). Despite the young age of these sediments, for most of the samples these two parameters fall within the range of values typical of Type II kerogen.

It was not possible to correlate the pyGC and pyGCMS data completely because pyGC uses a two-stage furnace pyrolysis technique and BP-1 GC stationary phase, while pyGCMS was performed on solvent extracted sediments using a one-stage CDS filament pyrolysis method and DB-5 GC stationary phase. The pyGC method gives the most reproducible recovery of the volatile products, but identification of these relies solely on the $\mathrm{GC}$ retention time. On the other hand, pyGCMS allows a much better identification of pyrolysis products, but the quantitative recovery of the more volatile compounds is less reproducible, even with the modified apparatus used here.

Chromatograms obtained from pyGC of Site 680 samples show a complex distribution of components. A key point is that these distributions are characteristic of sedimentary organic matter and not living organisms (cf. the chromatogram obtained from pyrolysis of cultured Thalassiosira eccentrica, a diatom) (Fig. 9). The main change with depth is the relative disappearance of a single major compound (Fig. 9). These components were identified by pyGCMS as dominantly aromatic and aliphatic hydrocarbons, with toluene as the major one. PyGCMS of solvent-extracted Site 680 samples'shows abundant aromatic and aliphatic hydrocarbons (e.g., alkylbenzenes, alkylnapthalenes, and alkyl-indenes) and nitrogenous compounds (e.g., alkylpyridines, alkylpyrroles, and alkyl-indoles). Although alkylphenols are abundant, there are surprisingly low amounts of other oxygen-containing compounds given the high abundance of organic oxygen in the samples. The aromatic components (including the alkylphenols) are all typical products of the pyrolysis of proteins (e.g., see Klok et al., 1984). The relative decrease of toluene with depth is accompanied by a decrease in proteins (Fig. 8), suggesting a relationship between the two. Alkylthiophenes and alkylfurans, which are expected pyrolysis products of sulfur-containing compounds and carbohydrates respectively, were present in only minor amounts. This is somewhat surprising, given the high $\mathrm{S}_{\text {org }} / \mathrm{C}_{\text {org }}$ ratios in the deeper samples (Table 7) and the carbohydrate contents of up to $8.7 \%$ (Table 9). However, note that pyGCMS did not allow detection of the most volatile compounds, and it is possible that, for example, $\mathrm{H}_{2} \mathrm{~S}$ or furan may not have been detected by our methods.

In addition to a homologous series of n-alkanes and several isoprenoids, a series of alkylbenzenes $\left(\mathrm{C}_{6} \mathrm{H}_{5} R\right)$, extending up to $R=\mathrm{C}_{13} \mathrm{H}_{27}$, was identified by mass fragmentography. Similar distributions have been identified in Namibian shelf diatomaceous ooze (Klok et al., 1983). Differences were noted 

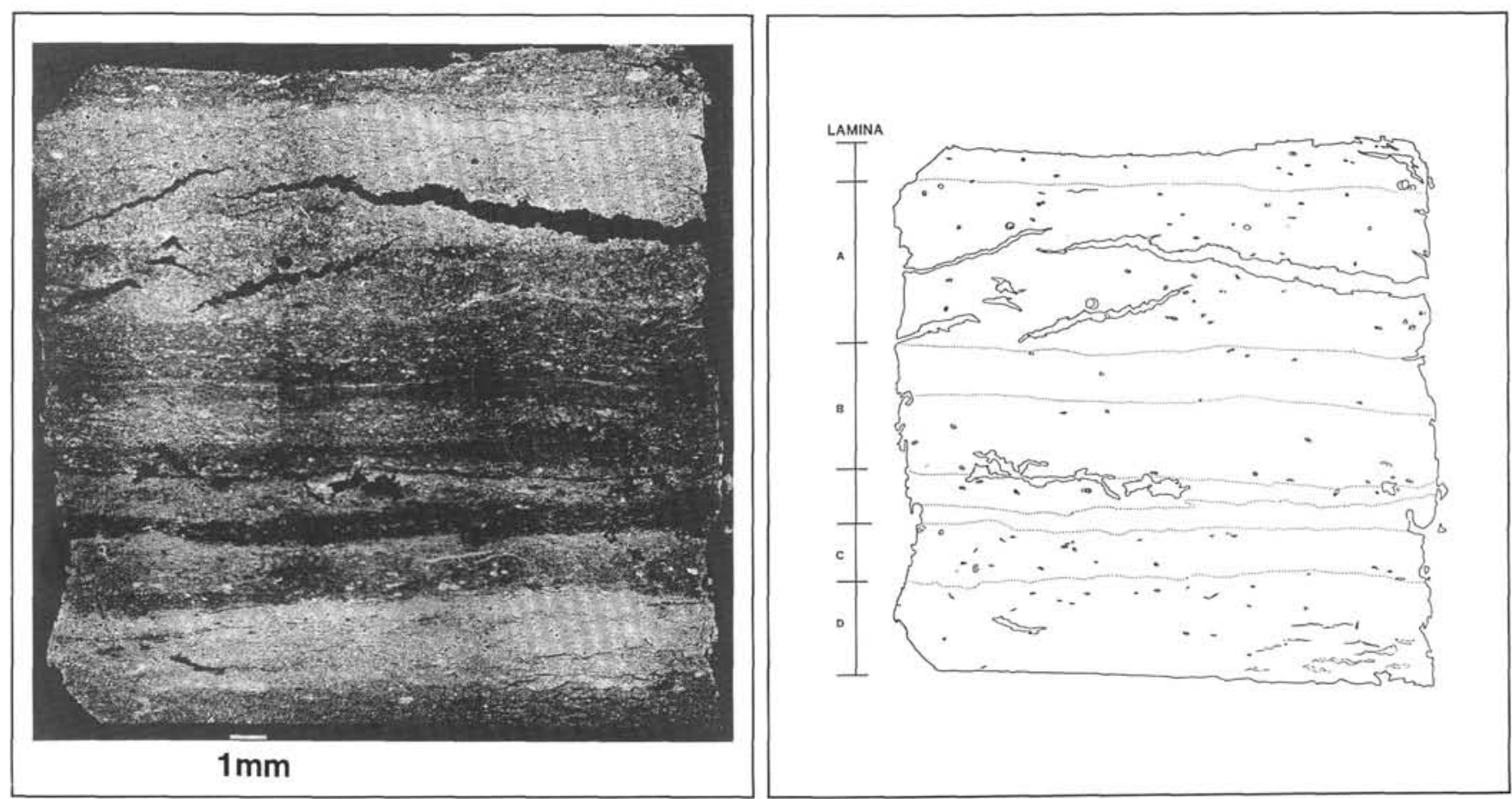

Figure 3. BEI mosaic and outline sketch of polished thin section through impregnated chip of Sample 112-680A-2H-1, 103-105 cm, showing composite laminations type I of Kemp and Kearsley, this volume). Tone represents contrast between low porosity/high clay content (bright) and high porosity/high value diatom content (dark) $(7.5 \times)$. Labels on sketch outline correspond to positions of subsamples taken for geochemical analysis.

Table 5. Lithological, paleontological, and chemical compositional data for the mosaic, Sample 112-680A-2H-1, 103-105 cm.

\begin{tabular}{|c|c|c|c|c|c|c|}
\hline & Colour & BEI tone & Texture & Diatom/foraminifer content & $\begin{array}{c}\text { Organic } \\
\text { carbon (\%) }\end{array}$ & $\begin{array}{c}\text { Carbonate } \\
(\%)\end{array}$ \\
\hline A & Dark brown & Light gray & $\begin{array}{l}\text { Low porosity. } \\
\text { No internal lamination. } \\
\text { Individual pellets common. } \\
\text { Medium clay. }\end{array}$ & $\begin{array}{l}\text { Coscinodiscus ratiatus group dominant. } \\
\text { Chaetoceras bristles and spores abundant. } \\
\text { Bolivina seminuda humilis Assemblage. }\end{array}$ & 6.4 & 9.8 \\
\hline B & $\begin{array}{l}\text { Buff with } \\
\text { brown } \\
\text { patches }\end{array}$ & Mid-gray & $\begin{array}{l}\text { Medium porosity. } \\
\text { Internal lamination. } \\
\text { Pelleted. } \\
\text { Sharp based. } \\
\text { Medium clay }\end{array}$ & $\begin{array}{l}\text { C. c.f. radiatus group dominant. } \\
\text { T. nitzchioides parva common. } \\
\text { Chaetoceras bristles and spores abundant. } \\
\text { Bolivina seminuda humilis Assemblage. }\end{array}$ & 3.7 & 13.8 \\
\hline C & Mid-brown & Mid-gray & $\begin{array}{l}\text { Medium porosity. } \\
\text { Internal lamination. } \\
\text { Pelleted. } \\
\text { Sharp base. } \\
\text { Low clay. }\end{array}$ & $\begin{array}{l}\text { C. c.f. radiatus group } \mathrm{v} \text {. abundant. } \\
\text { Chaetoceras } \text { bristles and spores } \mathrm{v} \text {. abundant. } \\
\text { Cyclotella striata } \mathrm{v} \text {. common. } \\
\text { Bolivina seminuda humilis Assemblage. }\end{array}$ & 5.4 & 8.7 \\
\hline D & $\begin{array}{c}\text { Dark brown } \\
\qquad \\
\text { darkens } \\
\text { upwards }\end{array}$ & $\begin{array}{l}\text { Light gray } \\
\text { Poor } \\
\text { internal } \\
\text { lamination. }\end{array}$ & $\begin{array}{l}\text { Low porosity. } \\
\text { Chaetoceras bristles and } \\
\text { spores v. abundant. } \\
\\
\text { Some pellets present. } \\
\text { Base not seen. } \\
\text { Medium clay. }\end{array}$ & $\begin{array}{l}\text { Cyclotella striata v. abundant. } \\
\text { Bolivina seminuda humilis Assemblage. }\end{array}$ & 6.7 & 8.2 \\
\hline
\end{tabular}

in the distributions of some alkylbenzene isomers with depth (e.g., $R=\mathrm{C}_{5} \mathrm{H}_{11}$; Fig. 10A) and also in isomers of some minor components (e.g., 2- and 3-methylthiophenes; Fig. 10B). The reasons for these differences are not known at present, but will be the subject of further study.

The absence of substituted methoxyphenols is evidence that lignin is not a major contributor to the organic matter in the Site 680 sediments. This is consistent with previous and present data from palynofacies analyses (Powell et al., this volume, and references therein). It would appear, therefore, that pyGC and pyGCMS products are generated from either lipids and proteins or the residual, biochemically uncharacterized "kerogen" (or both). The kerogen must be lipidic and proteinaceous in origin. A commonly assumed mechanism for the formation of humic substances, which are thought to be the precursors of kerogen, is that phytopIankton-derived proteins and carbohydrates may undergo the "Maillard" reaction in sediments to produce acidic melanoidins whose 
R. L. PATIENCE ET AL.

Table 6. Lithological, paleontological, and chemical compositional data for the mosaic, Sample 112-680A-10-5, 52-52 cm.

\begin{tabular}{|c|c|c|c|c|c|c|}
\hline & Colour & BEI tone & Texture & Diatom/foraminifer content & $\begin{array}{c}\text { Organic } \\
\text { carbon }(\%)\end{array}$ & $\begin{array}{c}\text { Carbonate } \\
(\%)\end{array}$ \\
\hline A & $\begin{array}{l}\text { Dark olive } \\
\text { green }\end{array}$ & Dark gray & $\begin{array}{l}\text { High porosity. } \\
\text { Fine internal lamination. } \\
\text { Planar and pelleted. } \\
\text { Sharp base. } \\
\text { Low clay. }\end{array}$ & $\begin{array}{l}\text { Chaetoceras bristles and spores v. abundant. } \\
\text { Delphineis spp. common. } \\
T \text {. nitzschioides v. common. } \\
\text { Foraminifers lost. }\end{array}$ & 1.7 & 0.56 \\
\hline B & $\begin{array}{l}\text { Mid-olive } \\
\text { green }\end{array}$ & Light gray & $\begin{array}{l}\text { Low porosity. } \\
\text { Poor internal lamination. } \\
\text { Some pellets present. } \\
\text { Sharp base. } \\
\text { High clay. }\end{array}$ & $\begin{array}{l}\text { Chaetoceras bristles and spores v. abundant. } \\
\text { Delphineis spp. common. } \\
T \text {. nitzschioides v. common. } \\
\text { Foraminifers lost. }\end{array}$ & 1.6 & 0.36 \\
\hline $\mathrm{C}$ & $\begin{array}{c}\text { Dark } \\
\uparrow \\
\text { pale } \\
\uparrow \\
\text { mid-olive } \\
\text { green }\end{array}$ & $\begin{array}{l}\text { Dark gray } \\
\text { light in } \\
\text { veins }\end{array}$ & $\begin{array}{l}\text { High porosity, low in veins. } \\
\text { Disrupted laminae. } \\
\text { Pelleted and planar. } \\
\text { Sharp base. } \\
\text { Low to medium clay. }\end{array}$ & $\begin{array}{l}\text { Chaetoceras bristles and spores v. abundant. } \\
\text { Delphineis spp. common. } \\
T \text {. nitzschioides common. } \\
\text { Bolivina seminuda humilis only. }\end{array}$ & 1.55 & 0.21 \\
\hline D & $\begin{array}{c}\text { Banded mid- } \\
\text { and pale } \\
\uparrow \\
\text { pale } \\
\uparrow \\
\text { mid-olive green }\end{array}$ & $\begin{array}{l}\text { Dark gray } \\
\text { light in } \\
\text { veins }\end{array}$ & $\begin{array}{l}\text { High porosity, low in veins. } \\
\text { Disrupted laminae, planar. } \\
\text { Sharp base. } \\
\text { Low to medium clay. }\end{array}$ & $\begin{array}{l}\text { Chaetoceras bristles and spores dominant. } \\
\text { Delphineis spp. common. } \\
\text { T. nitzschioides common. } \\
\text { Foraminifers lost. }\end{array}$ & 1.3 & 0.27 \\
\hline E & $\begin{array}{c}\text { Dark olive } \\
\text { green } \\
\uparrow \\
\text { darkens } \\
\text { upward }\end{array}$ & $\begin{array}{l}\text { Mid to light } \\
\text { gray }\end{array}$ & $\begin{array}{l}\text { Low porosity. } \\
\text { Some pelleted, fine } \\
\text { internal lamination. } \\
\text { Base not seen. } \\
\text { High clay. }\end{array}$ & $\begin{array}{l}\text { Chaetoceras bristles and spores v. abundant. } \\
\text { Delphineis spp. v. common. } \\
\text { A. senarius v. common. } \\
\text { Foraminifers lost. }\end{array}$ & 1.7 & 0.27 \\
\hline
\end{tabular}
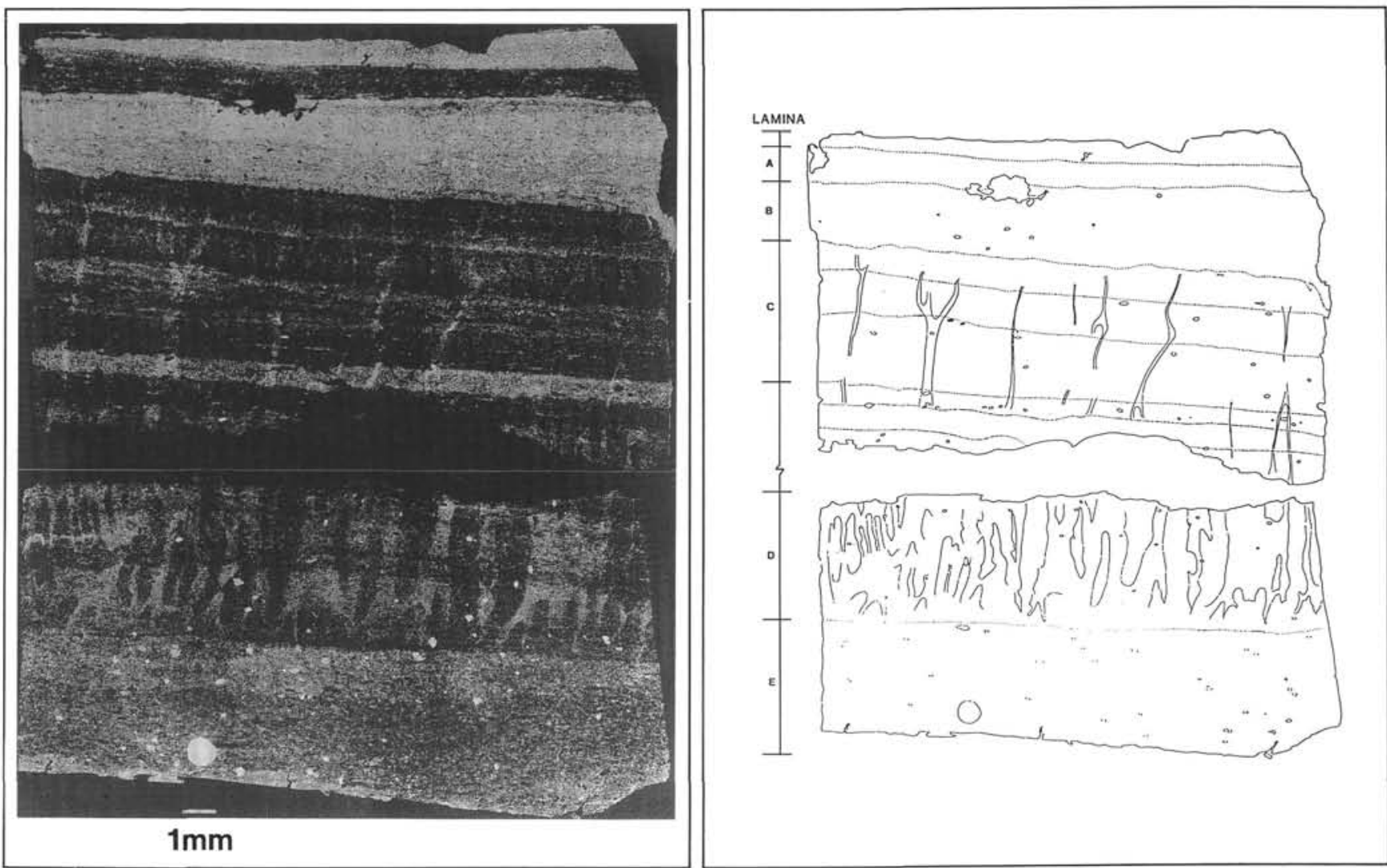

Figure 4. BEI mosaic and outline sketch of polished thin section through impregnated chip of Sample 112-680B-10H-5, 50-52 cm. Pale gray tones are clay-rich laminae; the central portion is disrupted by veins $(7.5 \times)$. Labels on sketch outline define subsamples taken for geochemical analysis. 


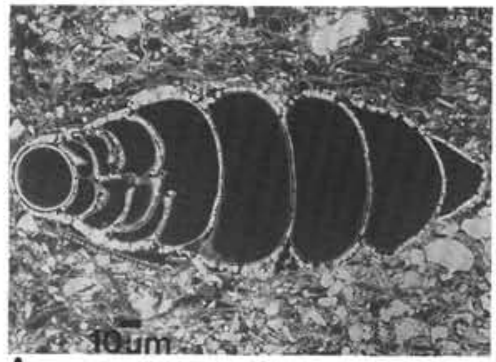

A
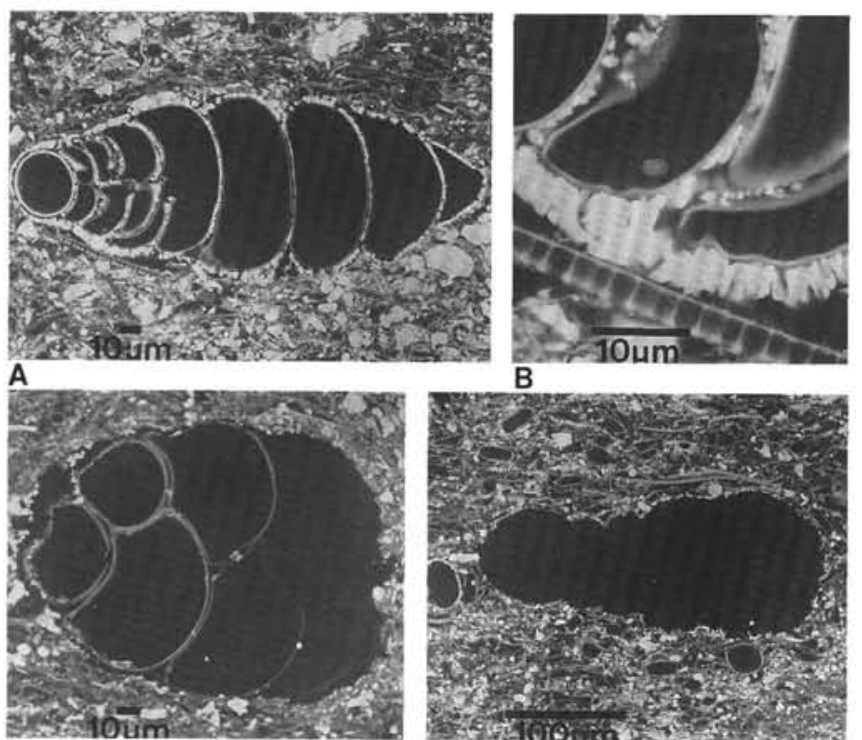

C

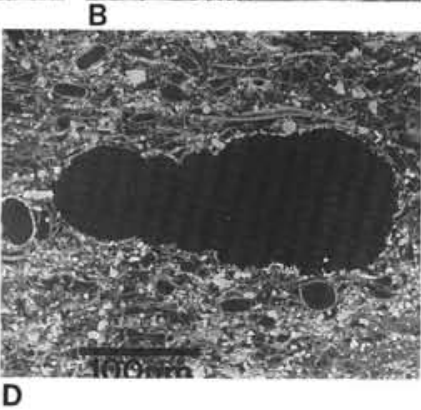

Figure 5. BEI of (A) section through B. seminuda humilis showing partial dissolution of carbonate test, organic walls intact, and restraining impregnating resin $(400 \times)$; (B) detail of (A) showing progressive loss of radial hyaline calcite "fibrous" test $(2000 \times)$; (C) section through $B$. seminuda humilis with calcite walls destroyed by dissolution, yet thin organic walls remain $(400 \times)$; (D) void, probably the position of Cassidela sp. test before dissolution (250×). All from Sample 112-680B-10H-5, 50-52 cm.

pyrolysis products are similar to humic substances (Larter and Douglas, 1980). However, in the Site 680 sediments, any carbohydrate incorporated into the kerogen must have been subsequently modified to the extent that the typical products of unaltered carbohydrates are not formed. Aromatic compounds, such as benzene and toluene, which are major components of the pyGC traces, can be formed by pyrolysis of intact proteins (e.g., when bacteria are pyrolyzed).

\section{CONCLUSIONS}

From elemental analysis and NMR data, organic matter in these sediments can be classified as "Type II." Considerable variation occurs in organic-carbon contents on a bulk-sample scale and also from lamina to lamina. The interlamina variations correlate with sediment porosity, diatom-rich laminae having lower organic-carbon contents than clay-rich laminae. The former also are substantially more porous, and this greater ease of access to the organic matter by microorganisms may have allowed for a greater degree of bacterial reworking, particularly in the sulfatereduction zone. The preserved organic matter originated overwhelmingly from bacterial and algal remains; there is no evidence for anything other than a minute influx of land plants. In samples from Site 680 , which were the most intensely studied, there has been rapid removal of carbohydrates and proteins at or above the sediment/water interface. The remaining carbohydrates and proteins decline in relative abundance with depth. PyGC and pyGCMS showed expected products derived from the pyrolysis of lipidic and proteinaceous material, whereas pyrolysis products attributable to carbohydrates and sulfur-containing organic compounds were not abundant. Both free and bound lipids also decrease in abundance with depth relative to the insoluble "uncharacterized" component. Total organic matter has a high heteroatom $(\mathrm{O}, \mathrm{N}, \mathrm{S})$ content (about 45 atoms per 100 carbon atoms) from elemental analysis and NMR, but the pyrolysis products identified do not reflect this abundance and predominantly hydrocarbons are seen. The degrees of aromaticity determined for four sediments (all about $30 \%$ ) are higher than would be found in the original living organic matter; this may be the result of either preferential concentration of aromatic species or aromatization reactions at or above the sediment surface. Apart from the high organic O/C ratio, these sediments have geochemical properties that are comparable to those from analogous depositional settings, but that have been far more deeply buried (i.e., 1000-2000 $\mathrm{m})$. All evidence supports the hypothesis that the key "kerogen-forming", processes take place during the earliest stages of sediment burial and diagenesis.

\section{ACKNOWLEDGMENTS}

We thank the following people from BP Research, Sunbury, for their analytical contributions: J. Price for CHNO data, I. Burholt for $\mathrm{XRF}$ analyses, I. Roberts for Iatroscan analyses, and I. Poplett for the NMR work. The assistance of C. Jones and J. Wells in experimental work and preparation of thin sections, D. Hicks for palynological preparations, and S. Deadman for photographic printing (all from Oxford Polytechnic) is gratefully acknowledged. G. Eglinton (Univ. of Bristol) kindly provided bulk samples for analysis, and A. Kemp (Univ. of Southampton) generously donated material from which the SEM mosaics were made and individual laminae were isolated. Plymouth Marine Laboratories generously donated the cultured diatom species. We also thank E. Suess for his assistance in translating the original manuscript into American. Work at Oxford Polytechnic and Plymouth Polytechnic was supported by grants from the Natural Environment Research Council (UK). Finally, we thank G. Eglinton and E. Nickless (NERC) for their organizational efforts. Permission to publish was granted by BP Research.

\section{REFERENCES}

Artem'yev, V. Y., 1970. Carbohydrates in the bottom sediments of the central Pacific. Oceanology, 10:508-513.

Behar, F., and Vandenbroucke, M., 1986. Répresentation chimique de la structure des kerogenes et des asphaltènes en fonction de leur origine et de leur dégre d'évolution. Rev. Inst. Français Pétrole, 41:173-188.

Bhosle, N. B., and Dhople, V. M., 1988. Distribution of some biochemical compounds in the sediments of the Bay of Bengal. Chem. Geol., 67:341-352.

Bordovskiy, O. K., 1965. Accumulation and transformation of organic substances in marine sediments. Mar. Geol., 3:3-114.

Brockmann, U., 1982. Monosaccharide composition of acid-hydrolyzable carbohydrates in particulate matter during a plankton bloom. Limnol. Oceanogr., 27:770-776.

Brown, F. S., Baedecker, M. J., Nissenbaum, A., and Kaplan, I. R., 1972. Early diagenesis in a reducing fjord, Saanich Inlet, British Columbia-III. Changes in organic constituents of sediment. Geochim. Cosmochim. Acta, 36:1185-1203.

Coleman, M. L., 1985. Geochemistry of diagenetic non-silicate minerals: kinetic considerations. Phil. Trans. Roy. Soc. London, A, 315:39-56.

Cowie, G. L., and Hedges, J. I., 1984a. Determination of neutral sugars in plankton, sediments, and wood by capillary gas chromatography of equilibrated isomeric mixtures. Anal. Chem., 56:497504.

1984b. Carbohydrate sources in a coastal marine environment. Geochim. Cosmochim. Acta, 48:2075-2087.

Degens, E. T., Reuter, J. H., and, Shaw, K.N.F., 1964. Biochemical compounds in offshore California sediments and sea waters. Geochim. Cosmochim. Acta, 28:45-66.

Dubois, M., Gilles, K. A., Hamilton, J. K., Rebers, P. A., and Smith, F., 1956. Colorimetric method for determination of sugars and related substances. Analyt. Chem., 28:350-356.

Faganeli, J., Ogorelec, B., Misic, M., Dolenec, T., and Pezdic, J., 1987. Organic geochemistry of two $40 \mathrm{~m}$ sediment cores from the Gulf of Trieste (northern Adriatic). Estuarine, Coastal and Shelf Sci., 25:157-167. 
Gerchakov, S. M., and Hatcher, P., 1972. Improved technique for analysis of carbohydrates in sediments. Limnol. Oceanogr., 17:938-943.

Greenfield, L. J., Hamilton, R. D., and Weiner, C., 1970. Nondestructive determination of protein, total amino acids and ammonia in marine sediments. Bull. Mar. Sci., 20:289-304.

Hamilton, S. E., and Hedges, J. I., 1988. The comparative geochemistries of lignins and carbohydrates in an anoxic fjord. Geochim. Cosmochim. Acta, 52:129-142.

Handa, N., 1966. Examination on the applicability of the phenol sulfuric acid method to the determination of dissolved carbohydrate in sea water. J. Oceanogr. Soc. Jpn., 22:79-86.

Handa, N., and Mizuno, K., 1973. Carbohydrates from lake sediments. Geochem. J., 7:215-230.

Henrichs, S. M., and Farrington, J. W., 1987. Early diagenesis of amino acids and organic matter in two coastal marine sediments. Geochim. Cosmochim. Acta, 51:1-15.

Henrichs, S. M., and Lee, C., 1984. Peru upwelling region sediments near $15^{\circ} \mathrm{S}$. 2. Dissolved free and total hydrolyzable amino acids. Limnol. Oceanogr., 29:20-34.

Hitchcock, G. L., 1977. The concentration of particulate carbohydrate in a region of the West Africa upwelling zone during March, 1974. Deep-Sea Res., 24:83-93.

Huc, A. Y., Durand, B., and Monin, J. C., 1978. Humic compounds and kerogens in cores from Black Sea sediments, Leg 42B-Holes 379A, 379B, and 380A. In Ross, D. A., Neprochnov, Y. P., et al., Init. Repts. DSDP , 42: Washington (U.S. Govt. Printing Office), 737-748.

Ittekot, V., Degens, E. T., and Honjo, S., 1984. Seasonality in the fluxes of sugars, amino acids and amino sugars to the deep ocean: Panama Basin. Deep-Sea Res., 31:1071-1083.

Klok, J., van der Knaap, J.J.M., de Leeuw, J. W., Cox, H. C., and Schenck, P. A., 1983. Qualitative and quantitative characterization of the total organic matter in a recent marine sediment. In Bjoroy, M., et al. (Eds.), Advances in Organic Geochemistry, 1981: Chichester (Wiley), 813-818.

Klok, J., Baas, M., Cox, H. C., de Leeuw, J. W., Rijpstra, W.I.C., and Schenk, P. A., 1984. Qualitative and quantitative characterization of the total organic matter in a recent marine sediment (Part II). Org. Geochem., 6:265-278.

Larter, S. R., and Douglas, A. G., 1980. Melanoidins-kerogen precursors and geochemical lipid sinks: a study using pyrolysis gas chromatography (PGC). Geochim. Cosmochim. Acta, 44:20872095.

Liebezeit, G., 1986. Pelagic and benthic sources of sedimentary carbohydrates in a shallow-water environment, Kiel Bight, Baltic. Mar. Geol., 71:201-213.

Maita, Y., Montani, S., and Ishii, J., 1982. Early diagenesis of amino acids in Okhotsk Sea sediments. Deep-Sea Res., 29:485498.

Mopper, K., 1977. Sugars and uronic acids in sediment and water from the Black Sea and North Sea with emphasis on analytical techniques. Mar. Chem., 5:585-603.

Morris, R. J., 1975. The amino acid composition of a deep-water marine sediment from the upwelling region northwest of Africa. Geochim. Cosmochim. Acta, 39:381-388.

Mueller, P. J., Suess, E., and Ungerer, C. A., 1986. Amino acids and amino sugars of surface particulate and sediment trap material from waters of Scotia Sea. Deep-Sea Res., 33:819-838.

Poutanen, E.-L., and Morris, R. J., 1983. The occurrence of high molecular weight humic compounds in the organic-rich sediments of the Peru continental shelf. Oceanol. Acta, 6:21-28.
Rogers, M. A., 1965. Carbohydrates in aquatic plants and associated sediments from two Minnesota lakes. Geochim. Cosmochim. Acta, 29:183-200.

Romankevich, E. A., 1984. Geochemistry of Organic Matter in the Ocean: Berlin (Springer-Verlag).

Rosen, H., 1957. A modified ninhydrin colorimetric analysis for amino acids. Arch. Biochem. Biophys., 67:10-15.

Rosenfeld, J. K., 1979. Amino acid diagenesis and adsorption in nearshore anoxic sediments. Limnol. Oceanogr., 24:1014-1021.

Scheidegger, K. F., and Krissek, L. A., 1982. Dispersal and deposition of eolian and fluvial sediments off Peru and northern Chile. Geol. Soc. Am. Bull., 93:150-162.

Schuette, G., and Schrader, H., 1979. Diatom Taphocoenoses in the coastal upwelling area off western South America. Nova Hedwigia, 64:359-378.

Standard Methods for the Examination of Water and Wastewater, 1981 (15th ed.), Am. Public Health Assoc., Am. Water Works Assoc., Water Pollution Control Federation, USA, 360-361.

Steinberg, S. M., Venkatesan, M. I., and Kaplan, I. R., 1987. Organic geochemistry of sediments from the continental margin off southern New England, USA-Part I. Amino acids, carbohydrates and lignin. Mar. Chem., 21:249-265.

Stevenson, F. J., and Cheng, C. N., 1970. Amino acids in sediments: recovery by acid hydrolysis and quantitative estimation by a colorimetric procedure. Geochim. Cosmochim. Acta, 34:77-88. 1972. Organic geochemistry of the Argentine Basin sediments: carbon-nitrogen relationships and Quaternary correlations. Geochim. Cosmochim. Acta, 36:653-671.

Suess, E., von Huene, R., et al., 1988. Proc. ODP, Init. Repts., 112: College Station, TX (Ocean Drilling Program).

Tanoue, E., 1985. Distribution and chemical composition of particulate organic matter in the Pacific sector of the Antarctic ocean. Trans. Tokyo Univ. Fish., 6:43-57.

Tissot, B. P., and Welte, D. H., 1984. Petroleum Formation and Occurrence: Berlin (Springer-Verlag), 2nd ed.

Uribe, E., Neshbya, S., and Fonseca, T., 1982. Phytoplankton community composition across the West Wind Drift off South America. Deep-Sea Res., 29:1229-1243.

Uzaki, M., and Ishiwatari, R., 1983. Determination of cellulose and non-cellulose carbohydrates in recent sediments by gas chromatography. J. Chromatogr., 260:487-492.

Vallentyne, J. R., 1963. Geochemistry of carbohydrates. In Breger, I. A. (Ed.), Organic Geochemistry: Oxford (Pergamon), 465-502.

Walsh, J. J., Premuzic, E. T., and Whitledge, T. E., 1981. Fate of nutrient enrichment on continental shelves as indicated by the $\mathrm{C} / \mathrm{N}$ content of bottom sediments. In Nihoul, J.C.J. (Ed.), Ecohydrodynamics: Amsterdam (Elsevier), 13-50.

Whelan, J. K., 1977. Amino acids in a surface sediment core of the Atlantic abyssal plain. Geochim. Cosmochim. Acta, 41:803-810.

Whiting, M. C., and Schrader, H., 1985. Late Miocene to Early Pliocene marine diatom and silicoflagellate floras from the Oregon coast and continental shelf. Micropalaeontol., 31:249-270.

Yamaoka, Y., 1983. Carbohydrates in humic and fulvic acids from Hiroshima Bay sediments. Mar. Chem., 13:227-237.

Yerino, L. N., and Maynard, J. B., 1984. Petrography of modern marine sands from the Peru-Chile Trench and adjacent areas. Sedimentology, 31:83-98.

Date of initial receipt: 12 October 1988

Date of acceptance: 5 July 1989

Ms 112B-191 
Table 7. Elemental atomic ratios for the bulk samples.

\begin{tabular}{|c|c|c|c|c|c|c|}
\hline \multirow{2}{*}{$\begin{array}{l}\text { Core, section } \\
\text { interval }(\mathrm{cm})\end{array}$} & \multirow[b]{2}{*}{$\mathrm{C}_{\text {org }}$} & \multicolumn{5}{|c|}{ Atomic ratio ${ }^{a}$} \\
\hline & & $\mathrm{H} / \mathrm{C}_{\text {org }}$ & $\mathrm{S} / \mathrm{C}_{\text {org }}$ & $\mathrm{N} / \mathrm{C}_{\text {org }}$ & O."org" $/ \mathrm{C}_{\text {org }}$ & $\mathrm{S}_{\text {org }} / \mathrm{C}_{\text {org }}{ }^{b}$ \\
\hline $112-679 \mathrm{D}-1 \mathrm{H}-1,25-35$ & 10.3 & 1.42 & 0.03 & 0.10 & 0.36 & n.d. \\
\hline $1 \mathrm{H}-1,73-83$ & 5.9 & 1.48 & 0.07 & 0.13 & 0.61 & n.d. \\
\hline $1 \mathrm{H}-2,131-141$ & 7.1 & 1.59 & 0.08 & 0.11 & 0.57 & n.d. \\
\hline $1 \mathrm{H}-4,88-98$ & 12.7 & 1.36 & 0.06 & 0.08 & 0.35 & n.d. \\
\hline $2 \mathrm{H}-2,48-58$ & 10.9 & 1.53 & 0.09 & 0.08 & 0.41 & n.d. \\
\hline $5 \mathrm{H}-2,111-123$ & 2.9 & 2.40 & 0.22 & 0.09 & 0.90 & n.d. \\
\hline $9 \mathrm{H}-1,59-71$ & 6.2 & 1.88 & 0.17 & 0.07 & 0.59 & n.d. \\
\hline $17 X-1,108-116$ & 0.6 & 5.00 & 0.87 & 0.43 & 3.12 & n.d. \\
\hline $12 \mathrm{X}-1,88-100$ & 2.4 & 2.50 & 0.41 & 0.03 & 1.06 & n.d. \\
\hline $112-680 \mathrm{~B}-1 \mathrm{H}-1,29-41$ & 11.0 & 1.53 & 0.04 & 0.08 & 0.40 & 0.010 \\
\hline $1 \mathrm{H}-1,70-82$ & 9.0 & 1.47 & 0.05 & 0.08 & 0.38 & 0.012 \\
\hline $1 \mathrm{H}-4,26-34$ & 5.0 & 1.68 & 0.12 & 0.07 & 0.57 & 0.039 \\
\hline $2 \mathrm{H}-3,29-37$ & 6.1 & 1.77 & 0.15 & 0.06 & 0.50 & 0.043 \\
\hline $3 \mathrm{H}-5,129-139$ & 8.5 & 1.69 & 0.14 & 0.04 & 0.37 & 0.056 \\
\hline $10 \mathrm{H}-6,88-100$ & 1.9 & 3.16 & 0.57 & 0.04 & 1.54 & 0.048 \\
\hline $112-681 \mathrm{~B}-1 \mathrm{H}-1,36-44$ & 5.1 & 1.88 & 0.08 & 0.08 & 0.68 & n.d. \\
\hline $1 \mathrm{H}-1,81-89$ & 4.0 & 1.80 & 0.09 & 0.06 & 0.60 & n.d. \\
\hline $2 \mathrm{H}-2,83-91$ & 2.4 & 2.00 & 0.23 & 0.04 & 0.94 & n.d. \\
\hline $2 \mathrm{H}-5,34-42$ & 1.6 & 3.00 & 0.54 & 0.04 & 1.50 & n.d. \\
\hline $5 \mathrm{H}-5,57-69$ & 2.6 & 2.77 & 0.20 & 0.07 & 0.92 & n.d. \\
\hline $10 \mathrm{H}-2,120-131$ & 4.0 & 1.80 & 0.16 & 0.06 & 0.62 & n.d. \\
\hline $13 X-5,100-112$ & 2.9 & 2.48 & 0.57 & 0.06 & 0.88 & n.d. \\
\hline $112-686 \mathrm{~B}-1 \mathrm{H}-1,30-39$ & 3.4 & 2.36 & 0.14 & 0.15 & 0.93 & n.d. \\
\hline $1 \mathrm{H}-1,87-96$ & 1.8 & 2.87 & 0.31 & 0.19 & 1.25 & n.d. \\
\hline $1 \mathrm{H}-3,79-89$ & 4.4 & 1.85 & 0.16 & 0.12 & 0.68 & n.d. \\
\hline $1 \mathrm{H}-5,80-90$ & 1.3 & 2.20 & 0.32 & 0.13 & 1.04 & n.d. \\
\hline $3 \mathrm{H}-2,33-45$ & 1.8 & 3.00 & 0.37 & 0.19 & 1.42 & n.d. \\
\hline $9 X-5,30-44$ & 2.5 & 2.54 & 0.22 & 0.14 & 1.17 & n.d. \\
\hline $15 X-5,32-42$ & 4.7 & 1.99 & 0.14 & 0.11 & 0.77 & n.d. \\
\hline
\end{tabular}

${ }^{a} \mathrm{H}=$ total hydrogen; $\mathrm{N}=$ total nitrogen; $\mathrm{S}=$ total sulfur; $\mathrm{O}$ "org" = pyrolyzable oxygen; $\mathrm{S}_{\text {org }}=$ organic sulfur; $\mathrm{C}_{\mathrm{org}}=$ organic carbon.

${ }^{b}$ Data from Mossmann et al. (this volume).

n.d. $=$ not determined. 


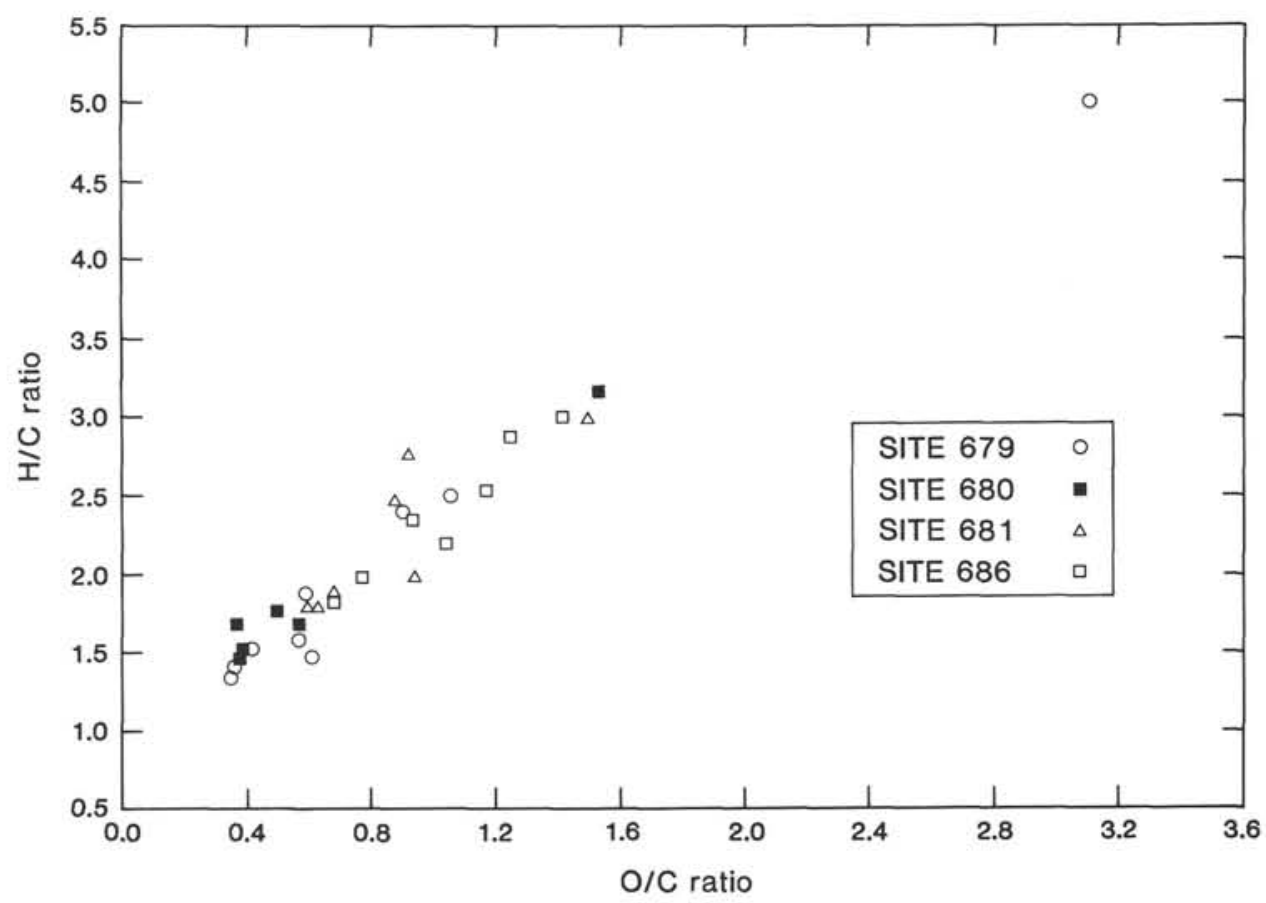

Figure 6. Plot of atomic $\mathrm{H} / \mathrm{C}_{\mathrm{org}}$ vs. O.. org" $/ \mathrm{C}_{\text {org }}$ ratios for all bulk samples.

Table 8. Degress of aromaticity and carbon-oxygen functionalities from NMR data for four bulk samples.

\begin{tabular}{lccccc}
\hline $\begin{array}{c}\text { Core, section, } \\
\text { interval }(\mathrm{cm})\end{array}$ & $\begin{array}{c}\mathrm{f}_{\mathrm{a}}{ }^{\mathrm{a}} \\
(\%)\end{array}$ & $\begin{array}{c}\mathrm{C}=\mathrm{O}^{\mathrm{b}} \\
(\%)\end{array}$ & $\begin{array}{c}\mathrm{COOR} \\
(\%)\end{array}$ & $\begin{array}{c}\mathrm{CO} \\
(\%)\end{array}$ & $\begin{array}{l}\mathrm{O} / \mathrm{C}^{\mathrm{c}} \\
\text { ratio }\end{array}$ \\
\hline $112-680 \mathrm{~B}-1 \mathrm{H}-1,70-82^{\mathrm{d}}$ & 29.6 & 3.1 & 8.4 & 20.5 & 0.30 \\
$112-680 \mathrm{~B}-1 \mathrm{H}-4,26-34^{\mathrm{d}}$ & 28.6 & 6.5 & 7.7 & 20.5 & 0.32 \\
$112-680 \mathrm{~B}-3 \mathrm{H}-5,129-139^{\mathrm{d}}$ & 25.1 & 5.0 & 7.3 & 20.4 & 0.30 \\
$112-680 \mathrm{~B}-10 \mathrm{H}-6,88-100^{\mathrm{e}}$ & 33.8 & 6.8 & 10.9 & 16.1 & 0.37 \\
\hline
\end{tabular}

$\mathrm{f}_{\mathrm{a}}=$ degree of aromaticity.

b $\mathrm{C}=\mathrm{O}=$ carbon in carbonyl groups; COOR = carbon in carboxyl groups; $\mathrm{CO}=$ carbon in alcohol or ether groups.

c atomic ratio.

d Error $= \pm 20 \%$ in NMR data.

e Error $= \pm 30 \%$ in NMR data. 


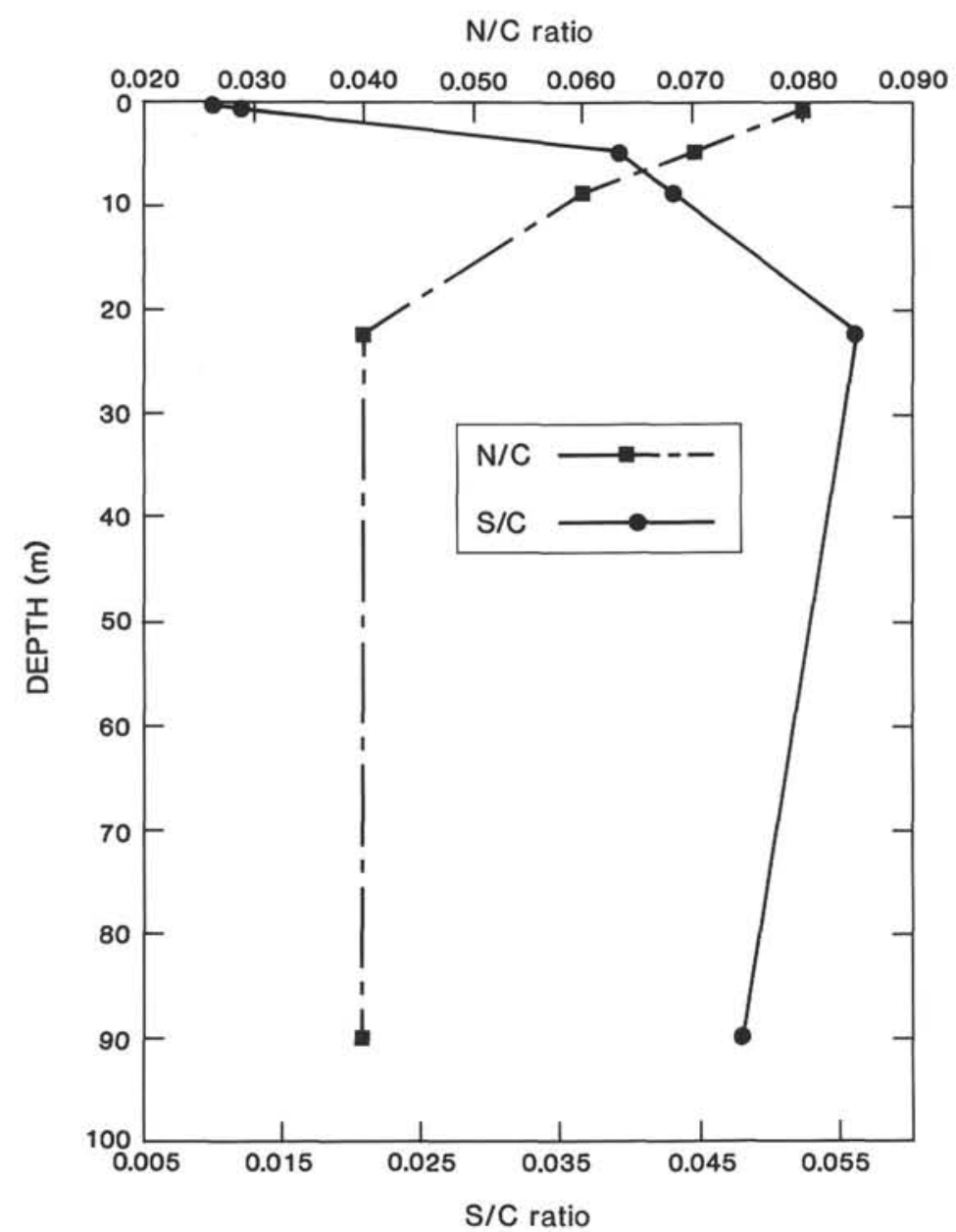

Figure 7. Variation in atomic N/C and organic S/C ratios with depth for Site 680. 


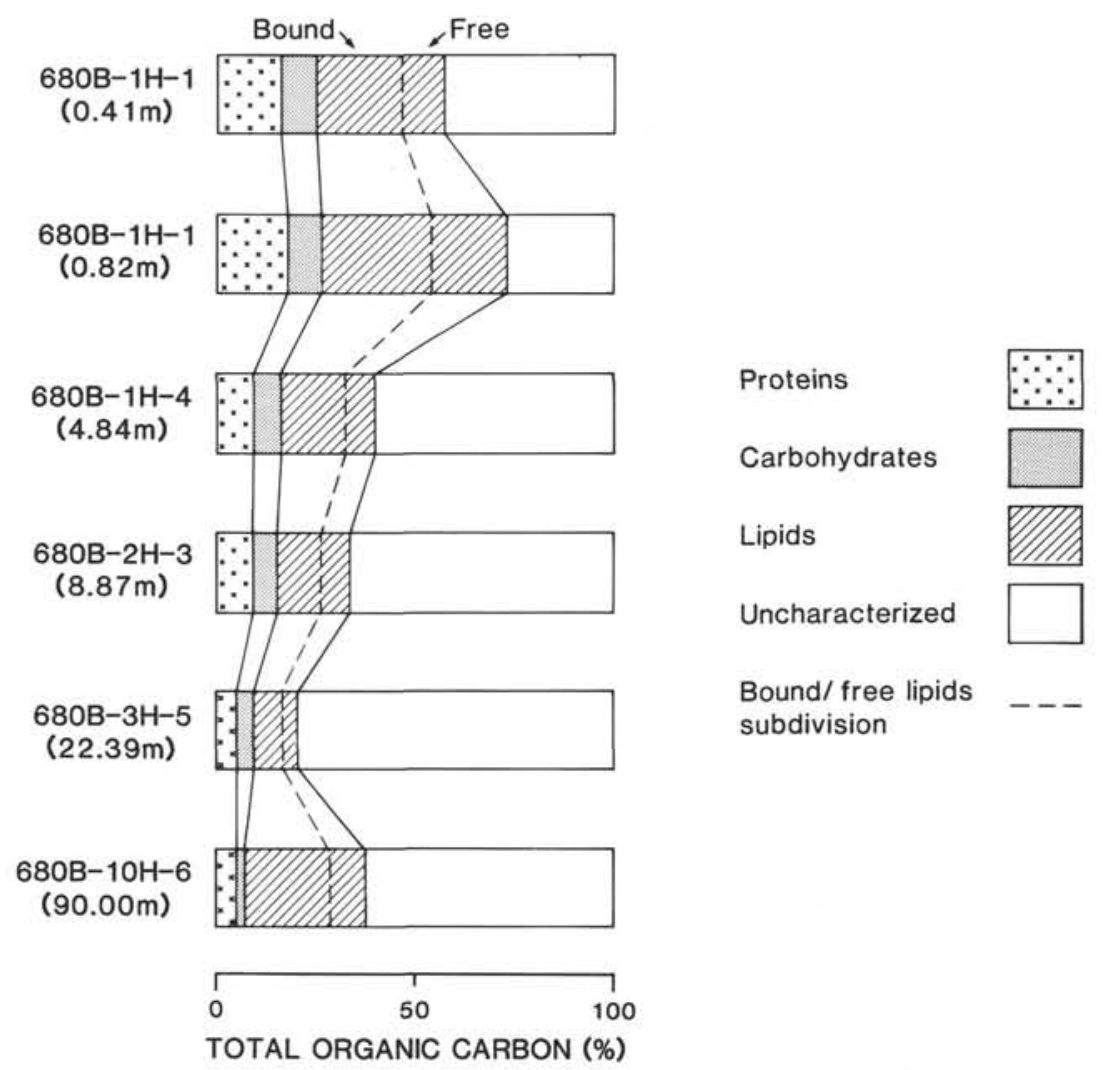

Figure 8 . Decline with depth in the relative contributions of main biochemical contributors to sediments at Site 680 .

Table 9. Biochemical composition of bulk samples from Site 680 .

\begin{tabular}{|c|c|c|c|c|c|c|c|c|c|c|}
\hline \multirow{2}{*}{$\begin{array}{l}\text { Core, section, } \\
\text { interval }(\mathrm{cm})\end{array}$} & \multicolumn{3}{|c|}{ Lipids } & \multicolumn{3}{|c|}{ Carbohydrates } & \multicolumn{3}{|c|}{ Proteins } & \multirow{2}{*}{$\begin{array}{c}\text { Total } \\
\text { biochem }\end{array}$} \\
\hline & free & bound & total & free & bound & total & free & bound & total & \\
\hline $112-680 \mathrm{~B}-1 \mathrm{H}-1,29-41$ & 10.5 & 22.0 & 32.5 & 0.05 & 8.7 & 8.7 & 0.38 & 15.5 & 15.9 & 57.1 \\
\hline $1 \mathrm{H}-1,70-82$ & 18.5 & 28.0 & 46.5 & 0.17 & 8.3 & 8.5 & 0.55 & 17.0 & 17.5 & 72.6 \\
\hline $1 \mathrm{H}-4,26-34$ & 7.6 & 17.0 & 25.4 & 0.15 & 6.3 & 6.5 & 1.49 & 8.0 & 9.5 & 40.5 \\
\hline $2 \mathrm{H}-3,29-37$ & 6.8 & 11.5 & 18.3 & 0.15 & 6.3 & 6.4 & 0.82 & 8.2 & 9.1 & 33.8 \\
\hline $3 \mathrm{H}-5,22-39$ & 4.6 & 7.5 & 12.1 & 0.05 & 3.5 & 3.6 & 0.44 & 4.6 & 5.1 & 20.8 \\
\hline $10 \mathrm{X}-6,88-100$ & 8.5 & 22.1 & 30.6 & 0.11 & 2.0 & 2.1 & 1.21 & 4.3 & 5.6 & 38.3 \\
\hline
\end{tabular}

All values in \% of total organic carbon. 

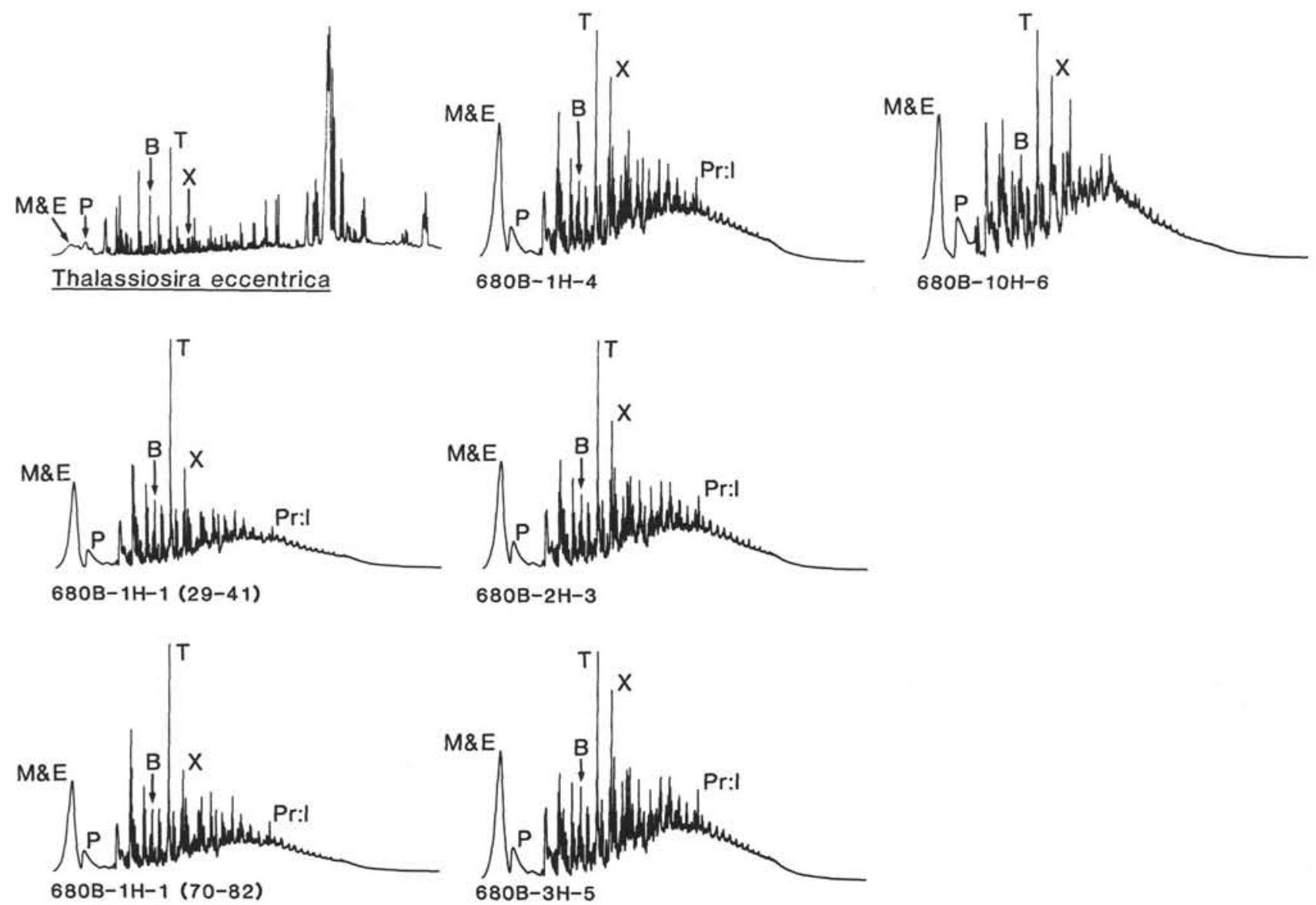

Figure 9. Pyrolysis-GC traces of sediments from Site 680 and a laboratory-cultured diatom species, Thalassiosira eccentrica. 


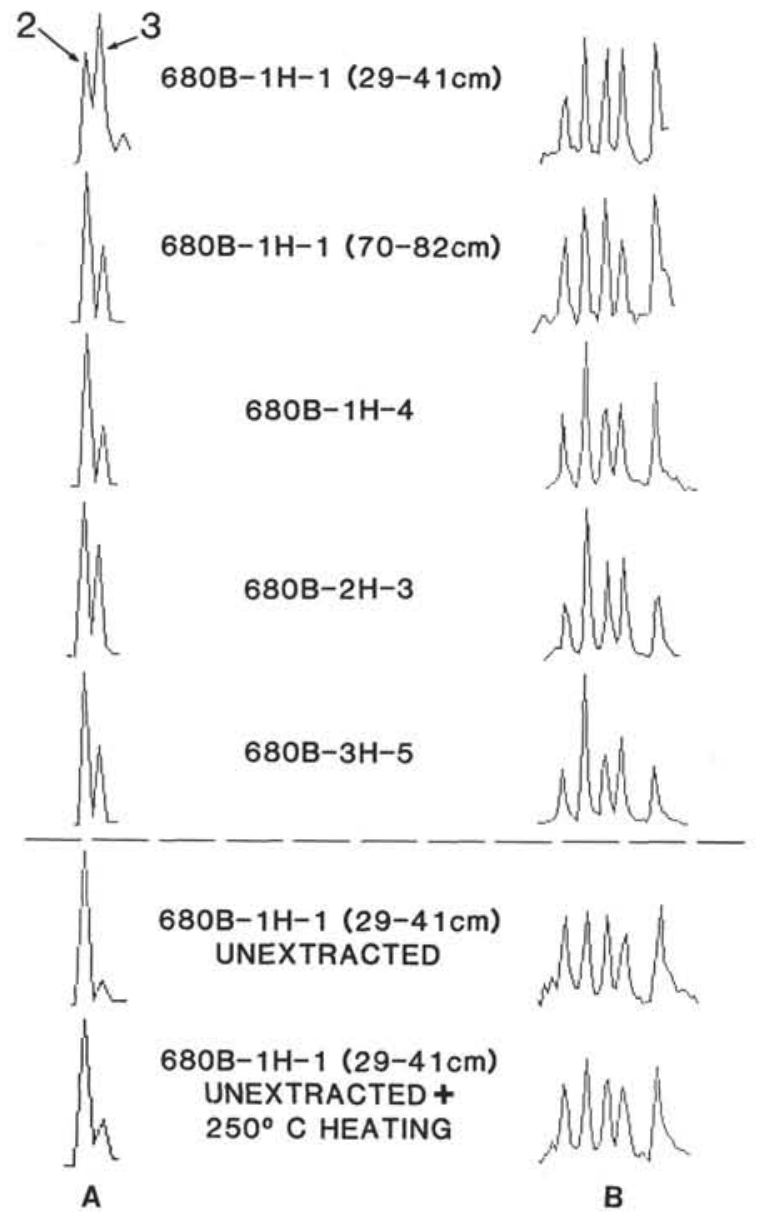

Figure 10. Mass fragmentograms of (A) m/z 155 (alkylbenzenes) and (B) $\mathrm{m} / \mathrm{z} 98$ (methylthiophenes) after pyrolysis-GCMS of sediments from Site 680 .

\section{APPENDIX}

\section{Elemental Analysis}

Carbon-hydrogen-nitrogen analyses were performed using a Carlo Erba elemental analyzer. A small sample $(5-10 \mathrm{mg})$ was accurately weighed into a tin capsule before combustion at $1800^{\circ} \mathrm{C}$ in an atmosphere of pure oxygen. Combustion products were swept through a catalytic bed of chromic oxide and silvered cobalt oxide, to give $\mathrm{CO}_{2}, \mathrm{H}_{2} \mathrm{O}$, and $\mathrm{N}_{2}$ /mixed nitrogen oxides. These gases were further passed through a reduction tube $\left(650^{\circ} \mathrm{C}\right)$ containing copper pellets to reduce all nitrogen oxides to $\mathrm{N}_{2}$. The $\mathrm{N}_{2}, \mathrm{CO}_{2}$, and $\mathrm{H}_{2} \mathrm{O}$ were separated with a $2 \mathrm{~m}$ Poropak Q5 gas chromatography (GC) column and quantified using a thermal conductivity detector (TCD). Pyrolyzable oxygen was determined with the same instrument, but under pyrolysis conditions. Samples of similar weight as the above were placed in silver capsules and pyrolyzed at $1050^{\circ} \mathrm{C}$ in a stream of helium. Any oxygen present was swept into a catalyst bed of $20 \%$ nickel coated onto carbon, where it was converted to $\mathrm{CO}_{2}$. This gas was separated from other pyrolysis products using a molecular sieve $(1 \mathrm{~m})$ and quantified by TCD.

\section{Determination of Proteins}

Proteins in recent marine sediments can be quantified after hydrolysis by characterization of individual amino acids (Degens et al., 1964; Henrichs and Farrington, 1987; Henrichs and Lee, 1984; Ittekot et al., 1984; Klok et al., 1983; Maita et al., 1982; Morris, 1975; Mueller et al., 1986; Rosenfeld, 1979; Steinberg et al., 1987; Whelan, 1977), or by quantification using a bulk amino acid assay, such as the ninhydrin method (Rosen, 1957) used here and previously (Greenfield et al., 1970; Stevenson and Cheng, 1970). The advantage of the latter method
Table 10. Basic geochemical parameters of the bulk samples.

\begin{tabular}{|c|c|c|c|c|c|}
\hline $\begin{array}{l}\text { Core, section, } \\
\text { interval }(\mathrm{cm})\end{array}$ & $\mathrm{C}_{\text {org }}{ }^{\mathrm{a}}$ & $\mathrm{S}_{1}$ & $\mathrm{~S}_{2}$ & $\mathrm{GOGI}^{\mathrm{b}}$ & $\mathrm{HI}^{\mathrm{c}}$ \\
\hline $112-679 \mathrm{D}-1 \mathrm{H}-1,25-35$ & 10.3 & 4.7 & 38.9 & 0.28 & 409 \\
\hline $1 \mathrm{H}-1,73-83$ & 5.9 & 2.9 & 18.2 & 0.24 & 325 \\
\hline $1 \mathrm{H}-2,131-141$ & 7.1 & 2.8 & 25.3 & 0.21 & 378 \\
\hline $1 \mathrm{H}-4,88-98$ & 12.7 & 5.5 & 42.7 & 0.21 & 359 \\
\hline $2 \mathrm{H}-2,48-58$ & 10.9 & 4.2 & 47.6 & 0.18 & 453 \\
\hline $5 \mathrm{H}-2,111-123$ & 2.9 & 1.6 & 9.2 & 0.23 & 341 \\
\hline $9 \mathrm{H}-1,59-71$ & 6.2 & 2.5 & 23.5 & 0.19 & 398 \\
\hline $17 X-1,108-116$ & 0.6 & 0.6 & 1.7 & n.d. & 361 \\
\hline $12 \mathrm{X}-1,88-100$ & 2.6 & 0.6 & 7.4 & 0.23 & 336 \\
\hline $112-680 \mathrm{~B}-1 \mathrm{H}-1,29-41$ & 11.0 & 5.3 & 40.1 & 0.27 & 386 \\
\hline $1 \mathrm{H}-1,70-82$ & 9.0 & 5.2 & 34.7 & 0.27 & 413 \\
\hline $1 \mathrm{H}-4,26-34$ & 5.0 & 2.8 & 16.6 & 0.23 & 361 \\
\hline $2 \mathrm{H}-3,29-37$ & 6.1 & 3.4 & 24.5 & 0.23 & 395 \\
\hline $3 \mathrm{H}-5,129-139$ & 8.5 & 4.3 & 34.3 & 0.22 & 413 \\
\hline $10 X-6,88-100$ & 1.9 & 1.4 & 5.7 & 0.24 & 300 \\
\hline $112-681 \mathrm{~B}-1 \mathrm{H}-1,36-44$ & 5.1 & 4.0 & 17.6 & 0.24 & 359 \\
\hline $1 \mathrm{H}-1,81-89$ & 4.0 & 2.4 & 10.7 & 0.23 & 306 \\
\hline $2 \mathrm{H}-2,83-91$ & 2.4 & 1.9 & 9.9 & 0.25 & 367 \\
\hline $2 \mathrm{H}-5,34-42$ & 1.6 & 1.0 & 4.2 & n.d. & 300 \\
\hline $5 \mathrm{H}-5,57-69$ & 2.6 & 1.7 & 9.8 & 0.25 & 392 \\
\hline $10 \mathrm{X}-2,120-131$ & 4.0 & 2.3 & 15.2 & 0.23 & 422 \\
\hline $13 X-5,100-112$ & 2.9 & 2.2 & 10.3 & 0.24 & 396 \\
\hline $112-686 \mathrm{~B}-1 \mathrm{H}-1,30-39$ & 3.4 & 1.8 & 9.3 & 0.24 & 282 \\
\hline $1 \mathrm{H}-1,87-96$ & 1.8 & 0.9 & 4.4 & n.d. & 293 \\
\hline $1 \mathrm{H}-3,79-89$ & 4.4 & 2.8 & 12.1 & 0.23 & 288 \\
\hline $1 \mathrm{H}-5,80-90$ & 1.3 & 0.7 & 3.6 & n.d. & 300 \\
\hline $3 \mathrm{H}-2,33-45$ & 1.8 & 1.2 & 5.2 & 0.26 & 325 \\
\hline $9 X-5,30-44$ & 2.5 & 1.3 & 7.1 & 0.28 & 296 \\
\hline $15 X-5,32-42$ & 4.7 & 2.2 & 14.0 & 0.25 & 333 \\
\hline
\end{tabular}

a Organic carbon (\%dry weight).

${ }^{\mathrm{b}} \mathrm{GOGI}=$ gas/oil ratio from pyrolysis GC

${ }^{\mathrm{c}} \mathrm{HI}=$ hydrogen index $=S_{2} / \% C_{\text {org }} \cdot 100$. n.d. $=$ not determined.

is that it is much easier, quicker, and cheaper; the disadvantage is that it quantifies amino groups, not amino acids. The absolute results presented here may thus include a small proportion of compounds that are not amino acids, but which react in the assay, if any such compounds are present.

The ninhydrin test is a colorimetric method involving the formation of a purple color from the reaction of reduced ninhydrin and amine groups (Rosen, 1957). Amino acids were quantified using a calibration curve set up using known concentrations of glycine. The response variations for different amino acids are minor, and we have ignored them.

Reagents required for the ninhydrin test were as follows:

1. Stock $\mathrm{NaCN}$ solution $(0.01 \mathrm{~mol} / \mathrm{L})$;

2. Acetate buffer $\left(2700 \mathrm{~g} \mathrm{NaOAc} .3 \mathrm{H}_{2} \mathrm{O}+500 \mathrm{~mL}\right.$ glacial acetic acid made up to $5 \mathrm{~L}$ with $\mathrm{H}_{2} \mathrm{O}$ );

3. Acetate/cyanide buffer $(0.2 \mathrm{mM} \mathrm{NaCN}$ in acetate buffer);

4. Ninhydrin (3\% wt./vol.) in methylcellosolve;

5. Diluent (2-propanol/water, 1:1);

6. Stock glycine solution $(10 \mathrm{mM})$;

7. Standard glycine solution $(0.4 \mathrm{mM})$.

A calibration curve was established using standard glycine solutions in the range from 0.04 to $0.4 \mathrm{mM}$. Ten solutions ( $1 \mathrm{~mL}$ each) of decreasing concentrations were created by dilution of the $0.4 \mathrm{mM}$ standard solution with water. A water blank was also kept. To each vial, containing $1 \mathrm{~mL}$ of standard or unknown solution, was added 0.5 $\mathrm{mL}$ of the acetate-cyanide solution and $0.5 \mathrm{~mL}$ of ninhydrin solution. The vials were immediately capped loosely and placed in a water bath at $100^{\circ} \mathrm{C}$ for $15 \mathrm{~min}$. After removal from the water bath, $10 \mathrm{~mL}$ of the diluent was added to each of the vials, which were then shaken and allowed to cool to room temperature. After adding diluent, the vials 
were centrifuged for $20 \mathrm{~min}$ to remove suspended particles that might affect absorbance readings. Aliquots of each solution were then transferred to a $1 \mathrm{~cm}$ cuvette, and the absorbance measured at $570 \mathrm{~nm}$ vs. the reagent blank. A calibration curve of absorbance vs. concentration was constructed using the standards. To account for any indigenous color present in the final reacted unknown solutions, a second set of 1-mL aliquots of unknowns was collected. To these solutions was added $0.5 \mathrm{~mL}$ of water and $0.5 \mathrm{~mL}$ of methylcellosolve; the resulting solutions were heated as before. Recorded absorbances were measured vs. a water blank $\left(1.5 \mathrm{~mL} \mathrm{H}_{2} \mathrm{O}, 0.5 \mathrm{~mL}\right.$ methylcellosolve, and $10 \mathrm{~mL}$ diluent), and the net absorbance subtracted from the value for the reacted solution. Thus, the resulting absorbance was the result of the reacted amino compounds present.

\section{Ammonia Correction}

Any ammonia or ammonium salts present in the water extract especially, or in the hydrolysate will react in the ninhydrin test. Experiments using ammonium chloride in place of glycine have shown that the former gives about $70 \%$ of the response of the latter (K. G. Bibby, unpubl. data). The amount of ammonia present can, in theory, be quantified independently using the phenate method (Standard Methods for the Examination of Water and Wastewater, 1981) and then subtracted from the ninhydrin test value. The test is colorimetric and measures the intensity of the blue color of indophenol produced by reaction of ammonia, hypochlorite, and phenol.

Reagents required for ammonia correction were:

1. Hypochlorous acid (1.0\% wt./vol. $\mathrm{NaOCl}$ adjusted to $\mathrm{pH} 6.5-7$ with $\mathrm{HCl}$ );

2. Manganous sulfate solution $(6 \mathrm{mM})$;

3. Phenate reagent $\left(2.5 \mathrm{~g} \mathrm{NaOH}\right.$ and $10 \mathrm{~g}$ phenol in $\left.100 \mathrm{~mL} \mathrm{H}_{2} \mathrm{O}\right)$;

4. Stock ammonia solution $\left(381.9 \mathrm{mg}\right.$ anhydrous $\mathrm{NH}_{4} \mathrm{Cl}$ in $1 \mathrm{~L}$ $\mathrm{H}_{2} \mathrm{O}$ ); $1 \mathrm{~mL}$ contains about $100 \mu \mathrm{g}$ of nitrogen or $123 \mu \mathrm{g}$ of ammonia;

5. Standard ammonia solution (dilute $5 \mathrm{~mL}$ of stock solution to 1 L with $\mathrm{H}_{2} \mathrm{O}$ ); $1 \mathrm{~mL}$ contains approximately $0.5 \mu \mathrm{g}$ of nitrogen or 0.615 $\mu \mathrm{g}$ of ammonia.

A calibration curve was constructed for standard solutions of ammonia in the concentration range of 0.05 to $0.5 \mu \mathrm{g}$ of $\mathrm{N} / \mathrm{mL}$. Solutions $(10 \mathrm{~mL}$ each) were made up in beakers $(50 \mathrm{~mL})$. One drop of manganous sulfate solution was added to each beaker; these beakers were then placed on magnetic stirrers and stirred vigorously, while $5 \mathrm{~mL}$ of the hypochlorous acid solution was added, followed by $0.6 \mathrm{~mL}$ of the phenate reagent (added dropwise). The color developed over a $10-\mathrm{min}$ period and was stable for $24 \mathrm{hr}$ only. A blank $(10 \mathrm{~mL}$ distilled water plus reagents) was also prepared and used in the spectrophotometer reference cell. The absorbance of standard solutions at $360 \mathrm{~nm}$ was measured, and a graph plotted of absorbance vs. $\mathrm{NH}_{3}-\mathrm{N}$ concentration.

Unknown samples were treated in an identical manner. Color intensity is affected by the age of the reagents; consequently, a standard was carried throughout each batch of samples. The concentration of ammonia (in $\mu \mathrm{g}$ of $\mathrm{NH}_{3}-\mathrm{N} / \mathrm{mL}$ ) is calculated thus:

$$
\mathrm{NH}_{3}-\mathrm{N}_{\text {sample }}=\mathrm{A}_{\text {sample }} \times \mathrm{HN}_{3}-\mathrm{N} \times \mathrm{N}_{\text {standard }}(\mu \mathrm{g} / \mathrm{mL})
$$

where $A$ is absorbance.

\section{Determination of Carbohydrates}

Carbohydrates were determined as free monosaccharides, after hydrolysis, using the phenol-sulfuric acid method (Dubois et al., 1956; modified by Gerchakov and Hatcher, 1972). This method has been adopted by many authors (e.g., Artem'yev, 1970; Dubois et al., 1956;
Faganeli et al., 1987; Gerchakov and Hatcher, 1972; Hitchcock, 1977; Tanoue, 1985) in preference to analysis of individual monosaccharides (e.g., by Brockmann, 1982; Cowie and Hedges, 1984a, 1984b; Hamilton and Hedges, 1988; Handa and Mizuno, 1973; Ittekot et al., 1984; Klok et al., 1983; Liebezeit, 1986; Mopper, 1977; Rogers, 1965; Steinberg et al., 1987; Uzaki and Ishiwatari, 1983; Yamaoka, 1983). The colorimetric test relies on the formation of an orange complex on reaction of phenol, sulfuric acid, and a carbohydrate. The carbohydrate concentration is measured in terms of micrograms of glucose per milliliter. Some variation exists in responses for different monosaccharides (Dubois et al., 1956; Handa, 1966); however, as glucose is a common constituent of polysaccharides and falls in the middle of the these variations, errors in quantifying carbohydrates by this method should be minimized. Most scientists recognize that there is no superior method available for determining total saccharides (as opposed to quantifying individual components, which is more time and energy intensive).

Reagents required were as follows:

1. Concentrated sulfuric acid;

2. Phenol solution $\left(50 \mathrm{mg} / \mathrm{mL}\right.$ in $\mathrm{H}_{2} \mathrm{O}$ );

3. Glucose stock solution $\left(0.1 \mathrm{mg} / \mathrm{mL}\right.$ in $\left.\mathrm{H}_{2} \mathrm{O}\right)$.

The calibration curve was set up using standards in the range of 5 to $100 \mu \mathrm{g}$ glucose $/ \mathrm{mL}$. Aliquots of $1,2,3,4,5,10$, and $20 \mathrm{~mL}$ from the stock solution were transferred to 8 -dram vials, and each aliquot was made up to a final volume of $20 \mathrm{~mL}$. Three aliquots ( $2 \mathrm{~mL}$ each) were then taken from each vial and transferred to a series of conical flasks, labelled $A_{i}$, and two series of vials labelled $B_{i}$ and $C_{i}$. To the $A$ series was added phenol solution $(2 \mathrm{~mL})$ and sulfuric acid $(10 \mathrm{~mL}$, with care). To the $B$ series was added water $(2 \mathrm{~mL}$ ) and sulfuric acid (10 $\mathrm{mL}$, carefully), and to the $C$ series was added phenol $(2 \mathrm{~mL})$ and water $(10 \mathrm{~mL})$. All additions were made with rapid mixing. The solutions were then transferred to $1-\mathrm{cm}$ cuvettes, and the absorbance read at $485 \mathrm{~nm}$. Absorbances of the $A$ series were measured vs. those of the $B$ series. Phenol absorbance was corrected by measuring the absorbance of the $C$ series vs. a blank containing water $(12 \mathrm{~mL})$ and phenol $(2 \mathrm{~mL})$. A standard curve of corrected absorbance ( $A$ vs. $B-C$ ) vs. glucose concentration can then be drawn. Unknown samples were treated identically to the standards.

\section{Quantification of Lipids}

Lipids are defined as organic solvent-soluble. The organic matter thus extracted is commonly referred to as "free lipid." In addition, young sediments contain a "bound lipid" fraction that becomes solvent-soluble after saponification (base hydrolysis). Free and bound lipids were quantified initially by weight; these results were checked using the Iatroscan method. The Iatroscan TLC/FID Mark III instrument (Iatron Laboratories) was operated under standard conditions for hydrocarbon analysis, using a rod scan speed of 2 (30-35 s running time), and air and hydrogen flow to the FID of 2000 and $180 \mathrm{~mL} / \mathrm{min}$, respectively. Data were collected with a VG Multichrom chromatography data-handling system. Standard solutions of palmitic acid (Koch Light Laboratories Ltd., purist grade) were created in chloroform (AR grade) to cover the concentration range of 0.6 to 22.7 $\mu \mathrm{g} / \mathrm{mL}$. Unknown samples were also dissolved in chloroform to provide solutions in the range of 0.9 to $2.5 \mu \mathrm{g} / \mathrm{mL}$ (by weight). Aliquots of $1 \mu \mathrm{L}$ palmitic acid standards and lipid samples were spotted onto the Chromarods (SIII). These rods were dried at $50^{\circ} \mathrm{C}$ in a nitrogen atmosphere for $5 \mathrm{~min}$ and then scanned in the instrument. Each sample was analyzed five times. Statistically, there was no difference in any case between the values obtained by weighing and those values from the Iatroscan method. In consequence, the results reported here are those obtained by weighing. 